\title{
OMICS Applications for Medicinal Plants in Gastrointestinal Cancers: Current Advancements and Future Perspectives
}

\author{
Rongchen Dai ${ }^{1,2 \dagger}$, Mengfan Liu ${ }^{1,2 \dagger}$, Xincheng Xiang ${ }^{1,2}$, Yang $\mathrm{Li}^{1,2}$, Zhichao $\mathrm{Xi}^{1,2 *}$ and \\ Hongxi $\mathrm{Xu}^{3 *}$
}

${ }^{1}$ School of Pharmacy, Shanghai University of Traditional Chinese Medicine, Shanghai, China, ${ }^{2}$ Engineering Research Center of Shanghai Colleges for TCM New Drug Discovery, Shanghai, China, ${ }^{3}$ Shuguang Hospital, Shanghai University of Traditional Chinese Medicine, Shanghai, China

\section{OPEN ACCESS}

Edited by:

Ke-Wu Zeng,

Peking University Health Science

Center, China

Reviewed by:

Xuanbin Wang,

Hubei University of Medicine, China

Songbai Liu,

Suzhou Vocational Health College,

China

${ }^{*}$ Correspondence:

Zhichao XI

xizhichao@shutcm.edu.cn

Hongxi $X u$

hxxu@shutcm.edu.cn

${ }^{\dagger}$ These authors have contributed equally to this work and share first

authorship

Specialty section:

This article was submitted to

Ethnopharmacology,

a section of the journal

Frontiers in Pharmacology

Received: 23 December 2021

Accepted: 20 January 2022

Published: 04 February 2022

Citation:

Dai R, Liu M, Xiang X, Li Y, Xi Z and Xu H (2022) OMICS Applications for Medicinal Plants in Gastrointestinal Cancers: Current Advancements and

Future Perspectives.

Front. Pharmacol. 13:842203

doi: 10.3389/fphar.2022.842203
Gastrointestinal cancers refer to a group of deadly malignancies of the gastrointestinal tract and organs of the digestive system. Over the past decades, considerable amounts of medicinal plants have exhibited potent anticancer effects on different types of gastrointestinal cancers. OMICS, systems biology approaches covering genomics, transcriptomics, proteomics and metabolomics, are broadly applied to comprehensively reflect the molecular profiles in mechanistic studies of medicinal plants. Single- and multi-OMICS approaches facilitate the unravelling of signalling interaction networks and key molecular targets of medicinal plants with antigastrointestinal cancer potential. Hence, this review summarizes the applications of various OMICS and advanced bioinformatics approaches in examining therapeutic targets, signalling pathways, and the tumour microenvironment in response to anticancer medicinal plants. Advances and prospects in this field are also discussed.

Keywords: gastrointestinal cancers, omics, medicinal plants, multi-omics, precision medicine, tumour heterogeneity

\section{INTRODUCTION}

Gastrointestinal cancers (GI cancers), mainly colorectal, gastric, hepatocellular, pancreatic and oesophageal cancers, contribute to high cancer-related mortality worldwide with significant morbidity and poor prognosis (Kuntz et al., 2021). Combining early detection and several therapeutic approaches, such as endoscopic therapy, surgery and chemotherapy, could improve the survival rate in patients with GI cancer. However, the therapeutic outcomes depend on numerous factors, including the cancer stage at diagnosis, different cancer subtypes, and patient susceptibility (Abdul-Latif et al., 2020). Unfortunately, current anticancer drug development for GI cancer is still forceless and costly; unavoidable adverse events or drug resistance are also nonnegligible obstacles.

Natural products provide a huge reservoir of components with potential pharmaceutical benefits, including anticancer, neuroprotective, and cardiovascular protection. Despite the complex phytochemical compositions of medicinal plants, modern technologies have identified numerous active anticancer ingredients, such as polysaccharides, triterpenes, flavonoids, proteins and amino acids. In the clinical community, several lead compounds derived from medicinal plants have been widely applied as first-line therapeutic agents. For example, paclitaxel isolated from Pacific yew was proven to be a chemotherapy medication used to treat various types of cancer (Mekhail and 


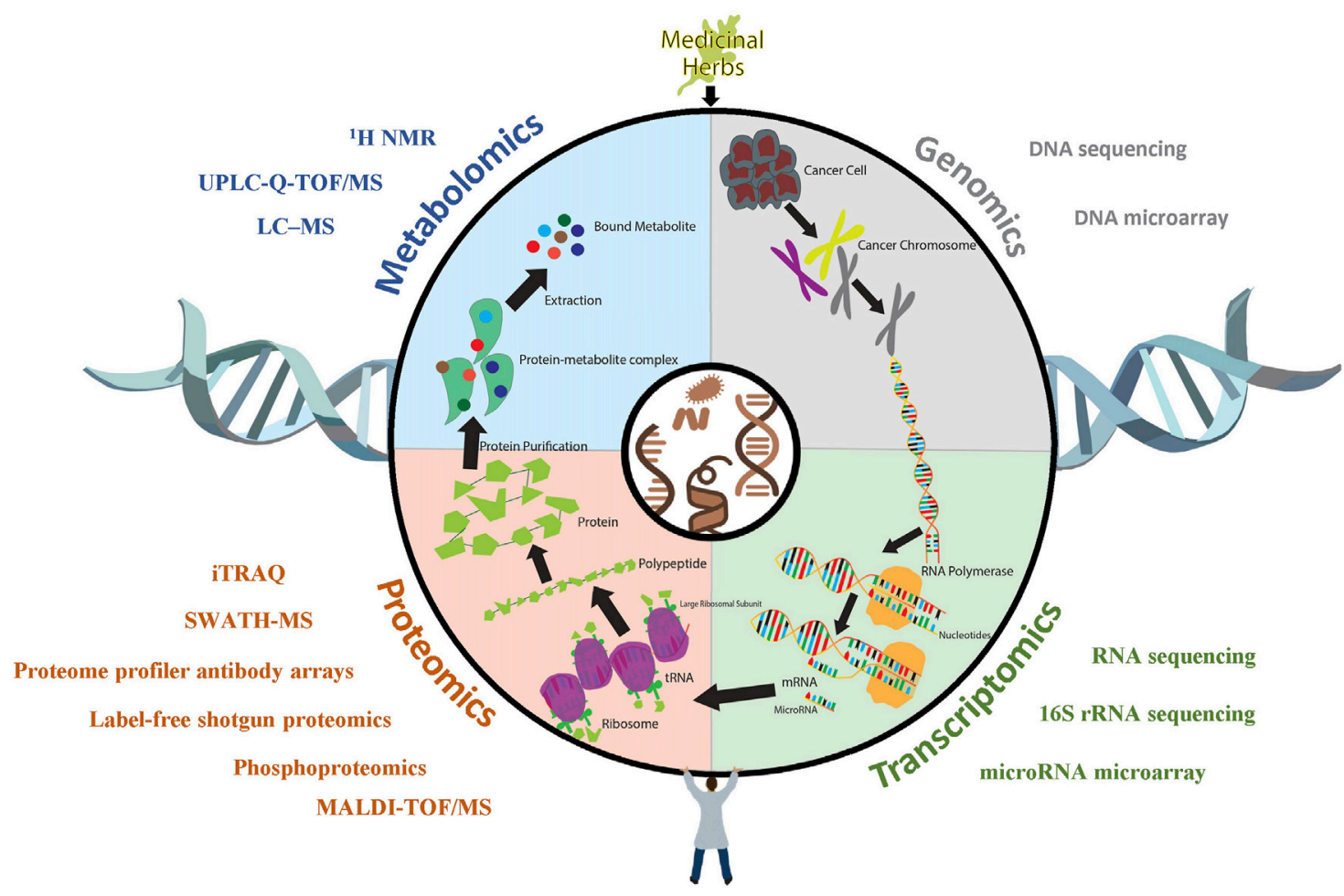

FIGURE 1 | The application of OMICS technologies in anti-Gl cancer research. Upon being treated with medicinal herbs, cancer cells undergo a series of biological processes, during which large amounts of molecular alterations are reflected in different dimensions, such as protein and mRNA expression levels and metabolite profiles. Various OMICS technologies, such as sequencing, microarrays, and iTRAQ assays, have been utilized to unravel the respective alterations of cancer in response to medicinal plants.

Markman, 2002). Moreover, GI cancer patients also benefit from medicinal plants as anticancer adjuvants in therapeutic effect enhancement, adverse reaction reduction, immune function improvement and drug resistance elimination ( $\mathrm{Hu}$ et al., 2016). Nevertheless, the underlying anti-GI cancer mechanisms upon herbal medicine treatment remain obscure, which has spawned further investigations on the global and systemic identification of key target molecules and signalling pathways.

OMICS is a series of approaches that aim to characterize and quantify the pools of biological molecules within organisms and covers numerous pieces of information, including structures, functions, and dynamics. Over the past decades, the integration of bioinformatic analysis with multiple OMICS datasets has allowed for a comprehensive understanding of genetic, proteomic, epigenetic and metabolic processes and thus has been suggested as a powerful and promising tool to uncover biomarkers and therapeutic targets (Nicora et al., 2020). Genomics covers all approaches that use DNA sequences to elucidate molecular profiles. For example, DNA microarray technology (collections of DNA probes arranged on a shared base) is used in specific gene searches or in gene polymorphism and expression analysis on a large scale (Bednár, 2000). Nextgeneration sequencing describes revolutionized genomic research and enables high-throughput, massively parallel sequencing of either DNA or RNA (Phillips, 2018). Proteins are the functional performers of genes, and the application of proteomics elaborates the identification and quantification of overall proteins present in a cell, tissue or organism. Genomics and transcriptomics expound the identity of proteins in an organism and seek to understand the structures and functions of particular proteins (Aebersold and Mann, 2003). Metabolomics provides comprehensive profiling of small molecule metabolites in different organisms at various life levels. By utilizing NMR and MS-based metabolomics, identified metabolites contribute to new drug discoveries and biomarker prediction (Spratlin et al., 2009).

This review focused on the current OMICS technologies utilized for understanding the actions of anticancer medicinal plants in the treatment of GI cancer (Figure 1). We summarized the scientific evidence of OMICS approaches for unravelling the complex signalling interaction networks, key target molecules, tumour microenvironment and host gut microbiota in response to anticancer herbal medicines (Figure 2). Current challenges and opportunities of OMICS were also discussed.

\section{APPLICATIONS OF OMICS IN GASTROINTESTINAL CANCERS}

\section{Colorectal Cancer}

Colorectal cancer (CRC), one of the most commonly diagnosed gastrointestinal cancers, is characterized by undetectable 


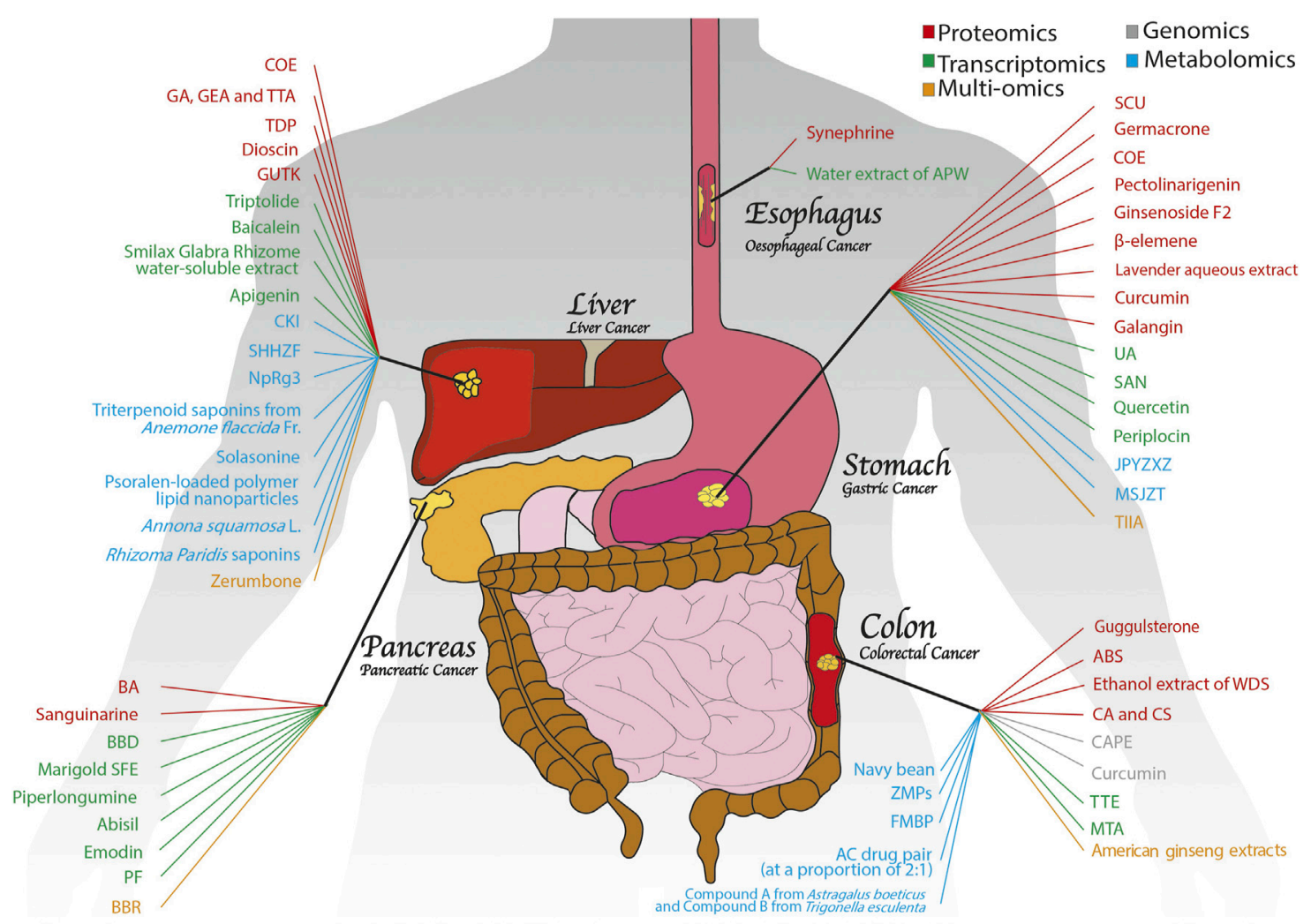

FIGURE 2 |An overview of medicinal plants with anti-GI cancer properties based on OMICS. Numerous medicinal plants have exhibited potent antitumour activities in Gl cancers, including colon, pancreatic, gastric, liver and oesophageal cancers. With the help of different OMICS approaches, such as proteomics, genomics, transcriptomics, metabolomics and multi-OMICS, the anti-GI cancer mechanisms of medicinal plants have been explored extensively.

preneoplastic lesions, rapid deterioration, early metastasis and high mortality (Bray et al., 2018). While early diagnosis and surgical excision combined with chemotherapy have been widely implemented in conquering colorectal cancer, the potential usage of medicinal plants as adjuvants has aroused momentum in this field. The applications of OMICS have merit in identifying antiCRC active compounds from medicinal plants and helping to unravel underlying anticancer mechanisms, including regulation of apoptosis, anticancer stress, and the host immune response (Table 1).

\section{Proteomics}

Leo et al. (2019) demonstrated that guggulsterone (GS), a plant sterol extracted from the gum resin of the tree Commiphora mukul (Hook. ex Stocks) Engl., significantly blocked HCT116 cell proliferation. Incorporating a mass spectrometry-based label-free shotgun proteomics approach and proteome profiler antibody arrays characterized novel proteomic signatures and identified significant protein expression differences between GS-treated and untreated HCT116 cells, including p53, TRIAL, TNF- $\alpha / N F-k B$, and apoptosis-related proteins. Differentially expressed proteins evaluated by proteomics indicated that Ankaferd hemostat (ABS), a mixture containing plant extracts of Thymus vulgaris L. Glycyrrhiza glabra L., Vitis vinifera L., Alpinia officinarum Hance, and Urtica dioica L., affected cellular and metabolic processes, such as glucose, fatty acid and protein metabolism, in Caco- 2 colon cancer cells. Moreover, ABS induced alterations of several cancer targets and upregulated tumour suppressor proteins (UCHL1 and RPL5) (Koçak et al., 2019). SWATHMS-based proteomics identified that the anti-inflammatory response caused by the ethanol extract of whole dried sugarcane (WDS) influenced the NFKB pathway by upregulating the oxidative stress regulator SELH and reducing phosphorylated NFkB. Further phosphoproteomics studies indicated that WDS promoted the phosphorylation of the cell stress regulators SIRT1 and EGFR while impeding the phosphorylation of PKA, PKC $\beta$ and c-Jun in an LPSstimulated inflammatory model of SW480 colon cancer cells (Bucio-Noble et al., 2018). Moreover, proteomic approaches can help discriminate different mechanisms of action between compounds with similar structures. Carnosic acid (CA) and carnosol (CS) are two orthodiphenolic diterpenes extracted from Salvia rosmarinus Schleid. (syn. Rosmarinus officinalis L.). They share an abietane carbon skeleton with hydroxyl groups at positions $\mathrm{C}-11$ and $\mathrm{C}-12$, while $\mathrm{CS}$ has a lactone moiety across the $\mathrm{B}$ ring, and $\mathrm{CA}$ has a free carboxylic acid group. A proteomics study based on dimethyl labelling combined with nano-LC-MS/MS revealed that the cellular response to CA induced ER stress, and CS treatment directly inhibited 20S proteasome catalytic activity in HT-29 cells, suggesting that 
TABLE 1 | The applications of OMICS on medicinal plants in Colorectal cancer.

\begin{tabular}{|c|c|c|c|c|c|}
\hline $\begin{array}{l}\text { Cancer } \\
\text { type }\end{array}$ & OMICs approach & Active component & $\begin{array}{l}\text { Medicinal } \\
\text { plant/Formulation }\end{array}$ & $\begin{array}{l}\text { Main anti-tumour } \\
\text { mechanism }\end{array}$ & References \\
\hline \multirow[t]{16}{*}{$\begin{array}{l}\text { Colorectal } \\
\text { cancer }\end{array}$} & Proteomics & Guggulsterone & $\begin{array}{l}\text { Commiphora mukul (Hook. ex } \\
\text { Stocks) Engl }\end{array}$ & $\begin{array}{l}\text { Induction of intrinsic apoptosis, } \uparrow p 53 \text {, } \\
\downarrow \text { TRAIL and TNF protein expression, } \downarrow N F- \\
\kappa B \text { signaling pathway }\end{array}$ & Leo et al. (2019) \\
\hline & & Ankaferd hemostat & $\begin{array}{l}\text { Thymus vulgaris L., } \\
\text { Glycyrrhiza glabra L., Vitis } \\
\text { vinifera L., Alpinia officinarum } \\
\text { Hance, and Urtica dioica L }\end{array}$ & $\begin{array}{l}\text { Regulation of glucose metabolism, } \\
\uparrow U C H L 1 \text { and RPL5 protein expression }\end{array}$ & Koçak et al. (2019) \\
\hline & & $\begin{array}{l}\text { Ethanol extract } \\
\text { of WDS }\end{array}$ & Saccharum officinarum L & $\begin{array}{l}\uparrow S E L H, \downarrow \text { phosphorylated NFKB, } \\
\uparrow \text { phosphorylation of SIRT1 and EGFR, } \\
\downarrow \text { phosphorylation of PKA, PKC } \beta \text { and c-Jun }\end{array}$ & Bucio-Noble et al. (2018) \\
\hline & & Carnosic acid & $\begin{array}{l}\text { Salvia rosmarinus Schleid. } \\
\text { (syn. Rosmarinus officinalis L.) }\end{array}$ & $\uparrow$ ER stress & Valdés et al. (2017) \\
\hline & & Carnosol & $\begin{array}{l}\text { Salvia rosmarinus Schleid. } \\
\text { (syn. Rosmarinus officinalis L.) }\end{array}$ & $\downarrow 20 S$ proteasome catalytic activity & Valdés et al. (2017) \\
\hline & Transcriptomics & Polyphenol extract & $\begin{array}{l}\text { Thalassia testudinum Banks \& } \\
\text { Sol. ex K.D.Koenig }\end{array}$ & $\begin{array}{l}\uparrow A T F 4-P 53-N F \kappa B \text { gene expression and } \\
\text { autophagy stress pathway }\end{array}$ & $\begin{array}{l}\text { Hernández-Balmaseda } \\
\text { et al. (2021) }\end{array}$ \\
\hline & & Methylthioacetic acid & Cucumis melo L & $\begin{array}{l}\text { Induction of dome formation, } \downarrow \text { cyclin E2 } \\
\text { and CDC25A gene expression }\end{array}$ & Kamimura et al. (2020) \\
\hline & Metabolomics & $\begin{array}{l}\text { Compound } \mathrm{A} \text { and } \\
\text { Compound } \mathrm{B}\end{array}$ & $\begin{array}{l}\text { Astragalus boeticus L. and } \\
\text { Trigonella esculenta Willd }\end{array}$ & $\begin{array}{l}\text { Reversion of drug resistance, } \uparrow a n t i- \\
\text { proliferative activity }\end{array}$ & Graziani et al. (2018) \\
\hline & & $\begin{array}{l}\text { Astragalus } \\
\text { membranaceus- } \\
\text { Curcuma wenyujin } \\
\text { extract }\end{array}$ & $\begin{array}{l}\text { Astragalus mongholicus } \\
\text { (Fishch.) Bunge (syn. } \\
\text { Astragalus propinquus } \\
\text { Schischkin) and Curcuma } \\
\text { aromatica Salisb. (syn. } \\
\text { Curcuma wenyujin Y.H.Chen } \\
\text { and C.Ling) }\end{array}$ & Regulation of several metabolic alterations & Sun et al. (2021) \\
\hline & & $\begin{array}{l}\text { Foxtail millet bran } \\
\text { peroxidase }\end{array}$ & Setaria italica (L.) P.Beauv & $\begin{array}{l}\downarrow \text { GPL metabolism, } \downarrow P C Y T 1 \alpha \text { and PCYT2 } \\
\text { expression }\end{array}$ & Shan et al. (2020) \\
\hline & & $\begin{array}{l}\text { American ginseng } \\
\text { extract }\end{array}$ & Panax quinquefolius $L$ & $\begin{array}{l}\text { Regulation of metabolites including } \\
\text { branched-chain amino acids, organic } \\
\text { acids, fatty acids and carbohydrates }\end{array}$ & Xie et al. (2015) \\
\hline & & Navy bean extract & Phaseolus vulgaris L & $\begin{array}{l}\text { Regulation of metabolic pathways, } \uparrow a m i n o \\
\text { acids, lipids, and bean-derived metabolites }\end{array}$ & Baxter et al. (2018) \\
\hline & & ZMP & Ziziphus jujuba Mill & $\begin{array}{l}\text { †fecal-microbiota diversity and probiotics } \\
\text { (Bifidobacterium, Bacteroides, } \\
\text { Lactobacillus and } \\
\text { Clostridium_sp_K4410MGS-306), } \uparrow \text { the } \\
\text { concentration of SCFAs }\end{array}$ & Ji et al. (2019) \\
\hline & Genomics & $\begin{array}{l}\text { Caffeic acid phenethyl } \\
\text { ester or Kaempferol }\end{array}$ & N.A. & $\begin{array}{l}\text { Abolishment of DNA mutations, such as } \\
\text { PIK3CA, KIT and ABL1 }\end{array}$ & Budisan et al. (2019) \\
\hline & & Curcumin & Curcuma longa L & $\begin{array}{l}\text { Reversion of CAC-induced DNA CpG } \\
\text { methylation downregulation }\end{array}$ & Guo et al. (2018) \\
\hline & $\begin{array}{l}\text { Multi-omics } \\
\text { (Transcriptomics and } \\
\text { metabolomics) }\end{array}$ & $\begin{array}{l}\text { American ginseng } \\
\text { extract }\end{array}$ & Panax quinquefolius $\mathrm{L}$ & $\begin{array}{l}\uparrow \text { glutamine and linolenic acid metabolites, } \downarrow \\
\text { proinflammatory cytokines, } \uparrow \text { beneficial } \\
\text { intestinal microbiome populations } \\
\text { (Firmicutes), } \downarrow \text { harmful ones (Bacteroidales } \\
\text { and Verrucomicrobia) }\end{array}$ & Wang et al. (2016) \\
\hline
\end{tabular}

" $\uparrow$ " represents increase, promote or up-regulate, while " $\downarrow$ " represents inhibit, suppress, decrease or down-regulate, NA, represents not available.

these two structurally similar bioactive compounds induced distinct anticancer mechanisms against CRC (Valdés et al., 2017).

\section{Transcriptomics}

Thalassia testudinum Banks \& Sol. ex K.D.Koenig polyphenol extract (TTE) suppressed angiogenesis and cancer cell proliferation in SW480 cells and a syngeneic CT26 allograft murine model. Transcriptome profiling and Ingenuity Pathway Analysis showed that TTE exerted anti-CRC activity by promoting autophagic stress and ATF4-P53-NFkB signalling
(Hernández-Balmaseda et al., 2021). Administration of methylthioacetic acid (MTA) extracted from Cucumis melo L. facilitated the formation of multicellular and cystic structures (termed domes) in human CRC RCM-1 cells, which is a promising differentiation therapy that aims to alleviate cancer malignancy without massacring normal cells. A microarray demonstrated that MTA-induced dome formation is at least partially associated with the downregulation of cyclin E2 and CDC25A, two crucial genes involved in G1 phase cell cycle control (Kamimura et al., 2020). 


\section{Metabolomics}

Chronic inflammation caused by inflammatory bowel disease (IBD), including ulcerative colitis and Crohn's disease, plays a critical role in tumorigenesis of the gastrointestinal tract (Lichtenstern et al., 2020). Mechanistically, DNA hypermethylation, reactive oxygen species (ROS) production and gut microbiota imbalance facilitate IBD, subsequently leading to the initiation and progression of colitisassociated carcinogenesis (CAC) (Rogler, 2014; Gagnière et al., 2016). A rapid ${ }^{1} \mathrm{H}$ NMR-based metabolomic approach identified 31 primary metabolites present in mixtures of fourteen Fabaceae species of Mediterranean vegetation that showed cytotoxicity against colon cancer cells, among which Compound A from Astragalus boeticus L. and Compound B from Trigonella esculenta Willd. were the two strongest components (Graziani et al., 2018). The Astragalus membranaceus (Fishch.) Bunge (syn. Astragalus propinquus Schischkin)-Curcuma aromatica Salisb. (syn. Curcuma wenyujin Y.H.Chen and C. Ling) (AC) drug pair (at a proportion of 2:1) demonstrated significant inhibitory effects on orthotopic transplantation colon tumour growth and metastasis in CT-26 tumour-bearing mice. Intriguingly, a UPLC-Q-TOF/MS metabolomics approach showed that AC treatment reversed several metabolic alterations induced by colon cancer, among which all-trans retinoic acid, a clinical anticancer chemotherapy drug, was significantly upregulated (Sun et al., 2021). One of the hallmarks of classical CAC is the metabolic imbalance resulting from abnormally elevated glycerophospholipids (GPLs). Shan and colleagues analysed the serum metabolite profiles of an AOM/DSS-induced CAC mouse model after foxtail millet bran peroxidase (FMBP) treatment by utilizing untargeted LC-MS-based metabolomics. The results speculated that FMBP blocked GPL metabolism by reducing the expression levels of key metabolic enzymes involved in phosphatidylcholine and phosphatidylethanolamine (such as PCYT1a and PCYT2), resulting in insufficient adenosine triphosphate to maintain CRC growth (Shan et al., 2020).

Plant-based dietary intake confers multiple beneficial bioactive components to the host and prevents humans from developing various diseases; in contrast, a high-fat diet will induce more adenomas and carcinomas (Baltgalvis et al., 2009). American ginseng attenuated Western-style high-fat diet-induced metabolic perturbation, reduced gut inflammation and tumorigenesis, and ameliorated the lifespan of $\mathrm{Apc}^{\mathrm{Min} /+}$ mice. Mechanistically, the metabonomic profiles showed that American ginseng markedly altered several metabolites, including branched-chain amino acids, organic acids, fatty acids and carbohydrates (Xie et al., 2015). Evidence suggests that fibre intake exhibits a negative correlation with the overall mortality of CRC (Song et al., 2018). In a randomized controlled trial, sufficient fibre intake by ingestion of dietary navy bean ( $35 \mathrm{~g} /$ day) for 4 weeks modulated the stool metabolome of overweight and obese CRC survivors compared with the vehicle control. Using a nontargeted metabolomics approach, navy bean consumption increased the abundance of amino acids, lipids, and bean-derived phytochemicals and protected against CRC by altering major metabolic pathways such as sterol, lysine, fatty acid, amino and inositol metabolism (Baxter et al., 2018).

Emerging evidence has highlighted the crucial role of the gut microbiota in potentiating intestinal carcinogenesis, and medicinal herbs can regulate gut dysbiosis by triggering the immune response, modulating microbial composition and activating immunological signalling pathways (Wong et al., 2017). Short-chain fatty acids (SCFAs) are produced when nondigestible plant carbohydrates reach the proximal colon and are metabolized by various microbiota, which alleviate CRC by modifying the gut microbial and immune systems (Gniechwitz et al., 2007; Tian et al., 2018). Ziziphus jujuba Mill. polysaccharides (ZMPs) modulated gut microbial communities by alleviating AOM/DSS-reduced fecal microbiota diversity and promoting the abundance of probiotics, including Bifidobacterium, Bacteroides, Lactobacillus and Clostridium sp._K4410MGS-306, in a C57BL/6 mouse model (Ji et al., 2019). Comparing the fecal metabolomics profiles with the model group, dietary ZMP consumption reduced intestinal $\mathrm{pH}$ in CRC mice and markedly increased the concentration of SCFAs (Ji et al., 2019).

\section{Genomics}

Applications of genomics can help identify the precise genes regulated by medicinal drugs. Next-generation sequencing revealed that either caffeic acid phenethyl ester (CAPE) or kaempferol abolished CRC-induced pathogenic DNA mutations, such as PIK3CA, KIT and ABL1, in RKO and HCT-116 cells (Budisan et al., 2019). By utilizing single-baseresolution DNA methylation sequencing, Guo et al. (2018) revealed that curcumin, the yellow pigment isolated from the rhizomes of turmeric (Curcuma longa L.), reversed CAC-induced downregulation of DNA CpG methylation in azoxymethane (AOM)- and dextran sodium sulfate (DSS)-induced CAC C57BL/6 mouse models.

\section{Multi-OMICS}

Oral administration of American ginseng (Panax quinquefolius L.) attenuated AOM/DSS-induced colitis and colon carcinogenesis in the A/J mouse model. Serum and fecal metabolomics analysis demonstrated that American ginseng reversed the AOM/DSS-induced decreases in glutamine and linolenic acid, these two metabolites exhibited anticancer potential by protecting the gut mucosa and suppressing the release of proinflammatory cytokines. Moreover, 16S rRNA sequencing revealed that American ginseng extracts maintained a healthy enteric microbiome community and protected against pathologic processes by obviously increasing beneficial intestinal microbiome populations such as Firmicutes and decreasing harmful populations such as Bacteroidales and Verrucomicrobia (Wang et al., 2016).

\section{Gastric Cancer}

Gastric cancer (GC) initiates with chronic gastritis and progresses to gastric atrophy, intestinal metaplasia, dysplasia, and finally to adenocarcinoma (Tan and Fielding, 2006). By utilizing various OMICS approaches, the unravelled anti-GC mechanisms upon 
TABLE 2 | The applications of OMICS on medicinal plants in gastric cancer.

\begin{tabular}{|c|c|c|c|c|c|}
\hline $\begin{array}{l}\text { Cancer } \\
\text { type }\end{array}$ & OMICs approach & $\begin{array}{l}\text { Active } \\
\text { component }\end{array}$ & $\begin{array}{l}\text { Medicinal } \\
\text { plant/Formulation }\end{array}$ & $\begin{array}{l}\text { Main anti-tumour } \\
\text { mechanism }\end{array}$ & References \\
\hline \multirow[t]{18}{*}{$\begin{array}{l}\text { Gastric } \\
\text { cancer }\end{array}$} & \multirow[t]{10}{*}{ Proteomics } & Scutellarein & Scutellaria baicalensis Georgi & $\begin{array}{l}\text { Induction of apoptosis, } \downarrow \text { PIK3CB and CIP2A } \\
\text { protein expression }\end{array}$ & $\begin{array}{l}\text { Saralamma et al. } \\
\text { (2020) }\end{array}$ \\
\hline & & Germacrone & Curcuma zedoaria (Christm.) & Induction of cell cycle arrest, apoptosis and & Fang et al. (2020) \\
\hline & & & Roscoe & $\begin{array}{l}\text { autophagosome formation, } \downarrow \text { HBXIP protein } \\
\text { expression }\end{array}$ & \\
\hline & & $\begin{array}{l}\text { Ethyl acetate } \\
\text { extract }\end{array}$ & Celastrus orbiculatus Thunb & $\begin{array}{l}\downarrow \text { HSP27 protein expression, } \downarrow N F-\kappa B / S n a i l \\
\text { pathway }\end{array}$ & Zhu et al. (2014) \\
\hline & & Pectolinarigenin & $\begin{array}{l}\text { Rutaceae Juss. family (Citrus L. } \\
\text { genus) }\end{array}$ & 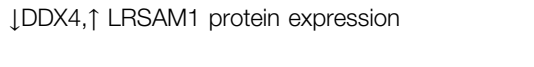 & Lee et al. (2018) \\
\hline & & Ginsenoside $F_{2}$ & Panax ginseng C.A.Mey & $\begin{array}{l}\uparrow R P L 26, \downarrow P R R 5, R P S 15, \mathrm{CISD} 2, \mathrm{Bcl}-\mathrm{xl} \text { and } \\
\text { NLRX1 protein expression }\end{array}$ & Mao et al. (2016) \\
\hline & & $\beta$-elemene & $\begin{array}{l}\text { Curcuma aromatica Salisb. } \\
\text { (syn. Curcuma wenyujin } \\
\text { Y.H.Chen and C.Ling) }\end{array}$ & $\begin{array}{l}\text { Induction of apoptosis, } \downarrow \text { TOPIla, } \uparrow P A K 1 \mid \mathrm{P} 1 \text { and } \\
\text { BTF protein expression }\end{array}$ & Liu et al. (2014) \\
\hline & & Aqueous extract & Plectranthus ecklonii Benth & $\begin{array}{l}\downarrow \text { Annexin1, anolase1 and HSP70 protein } \\
\text { expression }\end{array}$ & $\begin{array}{l}\text { Zamanian-Azodi } \\
\text { et al. (2012) }\end{array}$ \\
\hline & & Curcumin & Curcuma longa $\mathrm{L}$ & Induction of apoptosis & Cai et al. (2013) \\
\hline & & Galangin & Alpinia officinarum Hance & $\begin{array}{l}\text { Induction of apoptosis, } \uparrow U c h-L 1, \downarrow \text { GSTP protein } \\
\text { expression }\end{array}$ & Kim et al. (2012) \\
\hline & \multirow[t]{5}{*}{ Transcriptomics } & Ursolic acid & $\begin{array}{l}\text { Various plants, such as Prunella } \\
\text { vulgaris } L\end{array}$ & $\begin{array}{l}\text { Regulation of Hippo pathway, } \uparrow \text { RASSF1, } \downarrow \text { YAP1, } \\
\text { FOXM1, KRAS and BATF genes }\end{array}$ & Kim et al. (2019) \\
\hline & & Sanguinarine & Sanguinaria canadensis L & $\begin{array}{l}\text { لmiR-96-5p, miR-29c-3p and MAP4K4 mRNA } \\
\text { expression, } \uparrow M A P K / J N K \text { signaling pathway }\end{array}$ & Dong et al. (2019) \\
\hline & & Quercetin & $\begin{array}{l}\text { Various plants, such as } \\
\text { Asparagus africanus Lam }\end{array}$ & $\begin{array}{l}\text { Induction of apoptosis, } \uparrow \text { ROS production, } \\
\text { \mitochondrial membrane potential, } \uparrow \text { TP53INP1, } \\
\text { \VEGFB and CDK10 gene expression }\end{array}$ & Shang et al. (2018) \\
\hline & & Periplocin & Periploca sepium Bunge & Induction of apoptosis, $\uparrow E R K 1 / 2-E G R 1$ pathway & Li et al. (2016) \\
\hline & & Ethanol extract & Smilax glabra Roxb & Induction of intrinsic apoptosis & Gao et al. (2011) \\
\hline & \multirow[t]{2}{*}{ Metabolomics } & Water extract & Jianpi Yangzheng Xiaozheng & $\begin{array}{l}\uparrow L \text {-glutamine, L-leucine, L-alloisoleucine, and } \\
\text { L-valine, } \downarrow \text { gluconolactone metabolism }\end{array}$ & Hou et al. (2021) \\
\hline & & MSJZT extract & Modified Si Jun Zi Tang & $\begin{array}{l}\text { Regulation of amino acid, glycolysis, and lipid } \\
\text { metabolism, } \downarrow \text { LDH, GS and PCYT2 mRNA and } \\
\text { protein expression }\end{array}$ & Nie et al. (2019) \\
\hline & $\begin{array}{l}\text { Multi-omics } \\
\text { (Transcriptomics and } \\
\text { proteomics) }\end{array}$ & Tanshinone IIA & Salvia miltiorrhiza Bunge & $\begin{array}{l}\downarrow \text { glucose consumption and pyruvate production, } \\
\text { induction of apoptosis and DNA damage, } \uparrow 553 \text {, } \\
\downarrow \text { AKT protein expression, } \uparrow P S M B 3, \downarrow R S 2 \text { protein } \\
\text { expression }\end{array}$ & Lin et al. (2015) \\
\hline
\end{tabular}

" $\uparrow$ " represents increase, promote or up-regulate, while " $\downarrow$ " represents inhibit, suppress, decrease or down-regulate.

medicinal herb treatment have been largely extended, including but not limited to mediating key molecules involved in apoptosis, cell cycle arrest, DNA repair, and cytoskeleton reorganization (Table 2).

\section{Proteomics}

Scutellarein (SCU), a flavone that is abundantly present in Scutellaria baicalensis Georgi, promotes cell death by inducing apoptosis in GC AGS and SNU484 cells. To verify the altered proteins after SCU treatment in GC cells, a comparative proteomics technique that integrated two-dimensional gel electrophoresis (2-DE), mass spectrometry (MS) and MALDITOF/MS analysis was implemented. The expression levels of two oncogenic molecules, phosphatidylinositol 4,5-bisphosphate 3kinase catalytic subunit $\beta$ isoform (PIK3CB) and protein phosphatase 2A (CIP2A), were significantly downregulated upon SCU treatment. Molecular docking studies suggested that SCU could directly bind to PIK3CB with ideal affinity (Saralamma et al., 2020). Germacrone, a monocyclic sesquiterpene isolated from Curcuma zedoaria (Christm.) Roscoe, inhibited GC by inducing cell cycle arrest at the G0/ G1 phase, inducing apoptosis and promoting autophagosome formation. Label-free proteomic and bioinformatic analyses revealed that germacrone significantly downregulated the protein level of hepatitis B X-interacting protein (HBXIP), which is aberrantly highly expressed in GC patient tumour tissues. Furthermore, overexpressing HBXIP effectively alleviated germacrone-induced cell cycle arrest and apoptosis, whereas si-HBXIP enhanced the inhibitory effect of germacrone on GC cell proliferation, suggesting that HBXIP was a potential target of germacrone in treating GC (Fang et al., 2020). Overexpression of HSP27, the most downregulated protein in response to Celastrus orbiculatus Thunb. ethyl acetate extract (COE) identified by proteomics, significantly abrogated the inhibitory effect of COE on SGC-7901 cells. Mechanistically, overexpressing HSP27 alleviated COE-inhibited

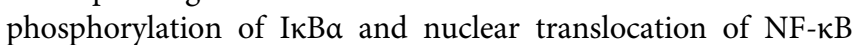
p65 and Snail (Zhu et al., 2014). In addition, proteomic 
approaches provided essential information for understanding the anti-GC mechanisms of pectolinarigenin present in citrus fruits (Lee et al., 2018), Ginsenoside F2 extracted from ginseng (Mao et al., 2016), $\beta$-elemene extracted from Curcuma aromatica Salisb. (syn. Curcuma wenyujin Y.H.Chen and C.Ling) (Liu et al., 2014), Lavender aqueous extract (Zamanian-Azodi et al., 2012), Curcumin isolated from Curcuma longa L. (Cai et al., 2013), and Galangin (Kim et al., 2012). Numerous identified proteins in response to these medicinal plants were found to be involved in cell cycle arrest, apoptosis, and other processes.

\section{Transcriptomics}

Ursolic acid (UA), a natural compound extracted from many herbal medicines, inhibited GC proliferation, invasion and migration in SNU484 and SNU638 cells. Microarray assays combined with Gene Ontology analysis further determined that UA markedly upregulated the Hippo pathway upstream target gene Ras association domain family (RASSF1) and downregulated the Hippo pathway downstream target gene YAP1 together with the oncogenes FOXM1, KRAS, and BATF. More importantly, RASSF1 silencing significantly reversed UAinduced upregulation of $\mathrm{p}$-YAP protein expression, suggesting that UA diminished tumorigenesis via the Hippo pathway by regulating RASSF1 (Kim et al., 2019). Sanguinarine (SAN), a benzophenanthridine alkaloid extracted from Sanguinaria canadensis L., suppressed GC BGC-823 cell proliferation both in vitro and in vivo. Microarray analysis following PCR verification revealed that SAN abolished the GC-induced abnormal expression of miR-96-5p, miR-29c-3p and MAP4K4 mRNA. These results indicated that SAN exhibited its anti-GC activity by inhibiting these miRNAs and activating the MAPK/JNK signalling pathway (Dong et al., 2019). Quercetin, a common component found in natural plants, induced apoptotic cell death in AGS human gastric cancer cells by augmenting ROS production and decreasing mitochondrial membrane potential $(\Delta \Psi \mathrm{m})$. A cDNA microarray assay further revealed that quercetin-altered differentially expressed genes were involved in the apoptosis pathway, such as TP53INP1, VEGFB and CDK10 (Shang et al., 2018). Similarly, a microarray assay revealed that Periplocin extracted from Periploca sepium Bunge and Smilax glabra Roxb. (SGR) exerts anticancer effects on gastric cancer cell lines by regulating both intrinsic (mitochondrial) and extrinsic (FAS and TNFR signalling) apoptotic pathways (Gao et al., 2011; Li et al., 2016).

\section{Metabolomics}

In a clinical trial of 36 GC patients, the traditional Chinese herbal formulation Jianpi Yangzheng Xiaozheng (JPYZXZ) reduced adverse drug reactions and improved the quality of life of patients after chemotherapy. Metabolomic analysis revealed that GC patients undergoing chemotherapy exhibited metabolic deficiencies in L-glutamine, L-leucine, L-alloisoleucine, and L-valine, which were reversed by JPYZXZ treatment. In addition, the clinical anti-GC mechanism of JPYZXZ was related to the inhibition of increased gluconolactone metabolism caused by GC (Hou et al., 2021).
Modified Si Jun Zi Tang (MSJZT) is another Chinese herbal formulation that shows anticancer effects in nude mouse GC models. HILIC and UHPLC-Q-TOF/MS-based metabolomics approaches revealed that modified MSJZT decreased the mRNA and protein levels of $\mathrm{LDH}$, glutamine synthetase, and PCYT2 in mouse plasma. These results suggested that the mechanisms underlying the anti-GC effects of MSJZT were at least partially mediated by regulating GC-induced energy metabolism dysfunction, such as amino acid, glycolysis, and lipid metabolism (Nie et al., 2019).

\section{Multi-OMICS}

Lin et al. integrated next-generation sequencing-based RNA-seq transcriptomics with quantitative proteomics to uncover that tanshinone IIA (TIIA), a diterpene quinone isolated from Salvia miltiorrhiza Bunge, inhibited glucose metabolism in GC cells. Mechanistically, TIIA reduced glucose consumption and pyruvate production by affecting the protein expression levels of G6PI, LDHB, MDH1, PCK2 and PGK1. Moreover, increased p53 and decreased $\mathrm{AKT}$ expression were found in response to TIIAinduced apoptosis and DNA damage, which may stimulate aerobic glycolysis in GC. Corresponding with the proteomics results, TIIA upregulated the PSMB3 protein level and downregulated the RS2 protein level, which are involved in cell cycle arrest and DNA repair (Lin et al., 2015).

\section{Liver Cancer}

Hepatocellular carcinoma (HCC) is mainly induced by liver cirrhosis due to viral infection or the excessive use of alcohol and exposure to aflatoxin. Anti-vascular mimicry (VM) has become a promising strategy to inhibit HCC progression by destroying the tumour blood supply system. OMICS technologies help characterize the anti-HCC mechanisms of numerous medicinal plants, including the induction of apoptosis, autophagy, and DNA damage and the regulation of several noncoding RNAs.

\section{Proteomics}

Celastrus orbiculatus Thunb. extract (COE) effectively suppressed VM formation in MHCC97-H cells and a tumour xenograft mouse model. Proteomics analysis identified that the expression of EphA2 was the most significantly decreased protein among 103 downregulated proteins upon COE treatment. Clinical resection of tumour tissues with VM structures from HCC patients expressed higher EphA2 than VM structure-free tissues, while blocking EphA2 by COE resulted in decreased cell invasion and damaged VM formation (Chu et al., 2021). A proteomics study revealed that three derivatives from Gamboge, namely, gambogic acid (GA), gambogenic acid (GEA) and 1,3,6,7-tetrahydroxyxanthone (TTA), inhibited HCC cell proliferation and induced apoptosis by regulating stathmin 1 (STMN1) and 14-3-3 $\sigma$. The following gain- and loss-of-function studies indicated that overexpressing STMN1 decreased the sensitivity of HCC cells to GA and GEA, whereas silencing STMN1 enhanced the sensitivity. Consistently, 14-3-3 $\sigma$ silencing reversed the suppressive effect of TTA on cell growth and apoptosis induction. Interestingly, bioinformatics 
TABLE 3 | The applications of OMICS on medicinal plants in liver cancer.

\begin{tabular}{|c|c|c|c|c|c|}
\hline $\begin{array}{l}\text { Cancer } \\
\text { type }\end{array}$ & OMICs approach & Active component & $\begin{array}{l}\text { Medicinal } \\
\text { plant/Formulation }\end{array}$ & $\begin{array}{l}\text { Main anti-tumour } \\
\text { mechanism }\end{array}$ & References \\
\hline \multirow[t]{23}{*}{$\begin{array}{l}\text { Liver } \\
\text { cancer }\end{array}$} & \multirow[t]{10}{*}{ Proteomics } & $\begin{array}{l}\text { Celastrus orbiculatus } \\
\text { extract }\end{array}$ & $\begin{array}{l}\text { Celastrus Orbiculatus } \\
\text { Thunb }\end{array}$ & $\begin{array}{l}\downarrow \text { EphA2 expression, inhibition of cell invasion and } \\
\text { VM formation }\end{array}$ & $\begin{array}{l}\text { Chu et al. } \\
(2021)\end{array}$ \\
\hline & & $\begin{array}{l}\text { Gambogic acid and } \\
\text { gambogenic acid }\end{array}$ & Garcinia hanburyi Hook. f & $\begin{array}{l}\text { Induction of apoptosis, } \downarrow \text { STMN1 protein } \\
\text { expression }\end{array}$ & $\begin{array}{l}\text { Wang et al. } \\
(2009)\end{array}$ \\
\hline & & $1,3,6,7-$ & Garcinia oblongifolia & Induction of apoptosis, $\uparrow 14-3-3 \sigma$ protein & \\
\hline & & tetrahydroxyxanthone & Champ. ex Benth & expression & $(2012 a)$ \\
\hline & & TDP & $\begin{array}{l}\text { Garcinia oblongifolia } \\
\text { Champ. ex Benth }\end{array}$ & Induction of apoptosis, $\downarrow$ Hsp27 protein expression & $\begin{array}{l}\text { Fu et al. } \\
(2012 b)\end{array}$ \\
\hline & & Dioscin & Dioscorea oppositifolia $L$ & $\begin{array}{l}\text { Induction of apoptosis, autophagy, and DNA } \\
\text { damage, } \downarrow \text { TIGAR mRNA and protein expression, } \\
\text { †p53 protein expression, } \downarrow \text { Akt/mTOR and CDK5/ } \\
\text { ATM pathways }\end{array}$ & $\begin{array}{l}\text { Mao et al. } \\
(2019)\end{array}$ \\
\hline & & GUTK & Garcinia yunnanensis $\mathrm{Hu}$ & $\uparrow$ PFN1, $\downarrow$ F-actin protein expression & $\begin{array}{l}\text { Shen et al. } \\
\text { (2016) }\end{array}$ \\
\hline & & Polysaccharides & $\begin{array}{l}\text { Viscum coloratum (Kom.) } \\
\text { Nakai }\end{array}$ & $\begin{array}{l}\uparrow \text { Vitronectin, } \downarrow \text { Histone } \mathrm{H} 3.1 \text { and Cytoskeletal } \\
9 \text { mRNA and protein expression }\end{array}$ & $\begin{array}{l}\text { Chai and Zhao, } \\
\text { (2017) }\end{array}$ \\
\hline & & Ethanol extract & $\begin{array}{l}\text { Antrodia Cinnamomea T.T. } \\
\text { Chang and W.N. Chou }\end{array}$ & Induction of apoptosis and ER stress & $\begin{array}{l}\text { Chen et al. } \\
(2020)\end{array}$ \\
\hline & & PZH extract & Pien Tze Huang & 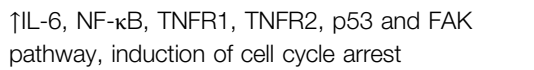 & $\begin{array}{l}\text { Fan et al. } \\
(2020)\end{array}$ \\
\hline & \multirow[t]{4}{*}{ Transcriptomics } & Triptolide & $\begin{array}{l}\text { Tripterygium wilfordii } \\
\text { Hook } \mathrm{f}\end{array}$ & $\begin{array}{l}\downarrow \mathrm{miR}-17-92 \text { and miR-106b-25 expression, } \uparrow \mathrm{BIM} \text {, } \\
\text { PTEN, and p21, } \downarrow \text { c-Myc and ERCC3 protein } \\
\text { expression }\end{array}$ & Li et al. (2018a) \\
\hline & & Baicalein & $\begin{array}{l}\text { Scutellaria baicalensis } \\
\text { Georgi }\end{array}$ & $\begin{array}{l}\text { Induction of ER stress, apoptosis, oxidative stress } \\
\text { and p53 signaling pathway, } \downarrow \text { HSPA1A and } \\
\text { HSPA1B gene expression, } \downarrow \text { HSP70 protein } \\
\text { expression }\end{array}$ & $\begin{array}{l}\text { Ma et al. } \\
(2019 a)\end{array}$ \\
\hline & & Water-soluble extract & Smilax glabra Roxb & $\downarrow$ TGF- $\beta 1$ signaling & $\begin{array}{l}\text { She et al. } \\
(2015)\end{array}$ \\
\hline & & Apigenin & $\begin{array}{l}\text { Various plants, such as } \\
\text { Scutellaria barbata D.Don }\end{array}$ & $\begin{array}{l}\uparrow 11 \text { miRNA expression (hsa-miR-24, hsa-miR- } \\
6769 b-3 p \text {, and hsa-miR-6836-3p, etc.), } \downarrow \text { hsa- } \\
\text { miR-181a-5p and hsa-miR-148a-3p expression }\end{array}$ & $\begin{array}{l}\text { Wang et al. } \\
\text { (2021) }\end{array}$ \\
\hline & \multirow[t]{8}{*}{ Metabolomics } & $\begin{array}{l}\text { Compound Kushen } \\
\text { Injection }\end{array}$ & $\begin{array}{l}\text { Radix sophorae } \\
\text { flavescentis and Rhizoma } \\
\text { smilacis glabrae }\end{array}$ & $\begin{array}{l}\text { Regulation of glycometabolism and amino acid } \\
\text { metabolism, } \uparrow \text { pyruvate, } \downarrow \text { glutamate }\end{array}$ & $\begin{array}{l}\text { Gao et al. } \\
(2018)\end{array}$ \\
\hline & & SHHZF gramule & Shuihonghuazi & $\begin{array}{l}\text { } \text { linoleic acid and oleic acid uptake and utilization, } \\
\text { } a \text { arachidonic acid metabolites, } \uparrow \text { PEMT activity, } \\
\downarrow \text { bile acid metabolism }\end{array}$ & $\begin{array}{l}\text { Bao et al. } \\
(2017)\end{array}$ \\
\hline & & NpRg3 & Panax ginseng C.A.Mey & $\begin{array}{l}\uparrow \text { free fatty acids, } \downarrow 3 \text {-indolepropionic acid and urea, } \\
\text { regulation of gut microbiota }\end{array}$ & $\begin{array}{l}\text { Ren et al. } \\
(2020)\end{array}$ \\
\hline & & Triterpenoid Saponins & $\begin{array}{l}\text { Anemone flaccida } \\
\text { F.Schmidt }\end{array}$ & $\begin{array}{l}\uparrow 1,3 \text {-diaminopropane, lauric acid, } 2,4- \\
\text { diaminobutyric acid } 2 \text {, and ribitol metabolites, } \\
\text { modulation of histidine, arginine, proline, beta- } \\
\text { alanine, glycine, serine, and threonine metabolism }\end{array}$ & $\begin{array}{l}\text { Han et al. } \\
(2019)\end{array}$ \\
\hline & & Solasonine & Solanum melongena L & $\begin{array}{l}\text { Induction of ferroptosis, } \downarrow \text { GPX } 4 \text { and GSS activity, } \\
\text { 个lipid ROS level }\end{array}$ & Jin et al. (2020) \\
\hline & & $\begin{array}{l}\text { Psoralen-loaded polymer } \\
\text { lipid nanoparticles }\end{array}$ & Psoralea corylifolia L & $\begin{array}{l}\text { Reversion of drug resistance, } \downarrow \text { retinoic acid and } \alpha \text { - } \\
\text { linolenic acid }\end{array}$ & Li et al. (2021) \\
\hline & & Annonaceous acetogenins & Annona squamosa L & $\begin{array}{l}\text { Regulation of glutathione, arginine, proline and } \\
\text { sphingolipid metabolism }\end{array}$ & $\begin{array}{l}\text { Ma et al. } \\
(2019 b)\end{array}$ \\
\hline & & Rhizoma Paridis Saponins & Paris polyphylla Sm & $\begin{array}{l}\text { \lactate, acetate, } \mathrm{N} \text {-acetyl amino acid and } \\
\text { glutamine signals }\end{array}$ & Qiu et al. (2016) \\
\hline & $\begin{array}{l}\text { Multi-omics } \\
\text { (Transcriptomics and } \\
\text { metabolomics) }\end{array}$ & Zerumbone & $\begin{array}{l}\text { Zingiber zerumbet (L.) } \\
\text { Roscoe ex Sm }\end{array}$ & $\begin{array}{l}\uparrow D I A B L O, C A S P 3, \text { BNIP3L, DEED and PMAIP1, } \\
\downarrow E R C C 2 \text { and HELLS gene expression, } \downarrow P I 3 K / \\
\text { AKT/mTOR and STAT3 signalling pathways, } \\
\downarrow^{13} \mathrm{C}_{6} \text {-glucose consumption and glycolytic } \\
\text { intermediate levels }\end{array}$ & $\begin{array}{l}\text { Wani et al. } \\
(2018)\end{array}$ \\
\hline
\end{tabular}

" $\uparrow$ " represents increase, promote or up-regulate, while " $\downarrow$ " represents inhibit, suppress, decrease or down-regulate.

analysis via AutoDock Vina modelling predicted that TTA

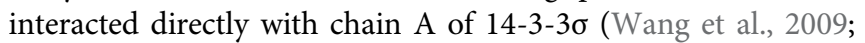
Fu et al., 2012a). Proteomic profiling analysis found that Hsp27 was one of the most significantly downregulated proteins in response to xanthone (TDP) isolated from Garcinia oblongifolia Champ. ex Benth. Silencing Hsp27 inhibited cell 
TABLE 4 | The applications of OMICS on medicinal plants in pancreatic cancer.

\begin{tabular}{|c|c|c|c|c|c|}
\hline $\begin{array}{l}\text { Cancer } \\
\text { type }\end{array}$ & OMICs approach & $\begin{array}{l}\text { Active } \\
\text { component }\end{array}$ & $\begin{array}{c}\text { Medicinal } \\
\text { plant/Formulation }\end{array}$ & $\begin{array}{l}\text { Main anti-tumour } \\
\text { mechanism }\end{array}$ & References \\
\hline \multirow[t]{9}{*}{$\begin{array}{l}\text { Pancreatic } \\
\text { cancer }\end{array}$} & \multirow[t]{2}{*}{ Proteomics } & Betulinic acid & $\begin{array}{l}\text { Rhamnaceae, Paeoniaceae, } \\
\text { Myrtaceae, and Betulaceae families }\end{array}$ & $\begin{array}{l}\text { TVAPB, BRE and APOA1, \TACO1, RNF167, } \\
\text { POLRMT, and DDX49 protein expression }\end{array}$ & Chiu et al. (2021) \\
\hline & & Sanguinarine & $\begin{array}{l}\text { Papaveraceae family, Sanguinaria } \\
\text { canadensis, Chelidonium majus, and } \\
\text { Argemone Mexicana }\end{array}$ & †DUSP4 protein expression & Singh et al. (2015) \\
\hline & \multirow[t]{6}{*}{ Transcriptomics } & Babao Dan & Babao Dan & $\begin{array}{l}\uparrow M T U S 1, \text { PDGFB, SOD3, and UCHL1, } \\
\text { \CDK15 and MYBL1 gene expression, } \\
\downarrow \text { MAPK cascade and Wnt signalling pathway }\end{array}$ & Song et al. (2020) \\
\hline & & Marigold SFE & Calendula officinalis $L$ & $\begin{array}{l}\text { Induction of autophagic cell death, } \uparrow \mathrm{BMP} 8 \mathrm{~B} \\
\text { gene expression }\end{array}$ & $\begin{array}{l}\text { Gómez de Cedrón } \\
\text { et al. (2019) }\end{array}$ \\
\hline & & Piperlongumine & Piper longum L & Regulation of oxidative stress and ER stress & Dhillon et al. (2016) \\
\hline & & Abisil & Abies sibirica Ledeb & GADD45, DUSP, and DDIT gene families & $\begin{array}{l}\text { Kudryavtseva et al. } \\
\text { (2016) }\end{array}$ \\
\hline & & Emodin & Rheum palmatum L & $\downarrow P 16$, RASSF1A and ppENK methylation & Zhang et al. (2015) \\
\hline & & Paeoniflorin & Paeonia lactiflora Pall & १HTRA3 gene expression & Li et al. (2017) \\
\hline & $\begin{array}{l}\text { Multi-omics } \\
\text { (Metabolomics and } \\
\text { transcriptomics) }\end{array}$ & Berberine & $\begin{array}{l}\text { Various plants, such as } \\
\text { Phellodendron amurense Rupr }\end{array}$ & $\begin{array}{l}\text { Regulation of citrate metabolism and } \\
\text { transportation, } \downarrow \text { KRAS, ACLY, ACO1, } \\
\uparrow C D K N 2 A \text { and SLC25A1 gene expression }\end{array}$ & Liu et al. (2020) \\
\hline
\end{tabular}

" $\uparrow$ " represents increase, promote or up-regulate, while " $\downarrow$ " represents inhibit, suppress, decrease or down-regulate.

TABLE 5 | The applications of OMICS on medicinal plants in oesophageal cancer.

\begin{tabular}{|c|c|c|c|c|c|}
\hline Cancer type & $\begin{array}{l}\text { OMICs } \\
\text { approach }\end{array}$ & $\begin{array}{l}\text { Active } \\
\text { component }\end{array}$ & $\begin{array}{l}\text { Medicinal } \\
\text { plant/Formulation }\end{array}$ & $\begin{array}{l}\text { Main anti-tumour } \\
\text { mechanism }\end{array}$ & References \\
\hline \multirow[t]{2}{*}{$\begin{array}{l}\text { Oesophageal } \\
\text { cancer }\end{array}$} & Proteomics & Synephrine & $\begin{array}{l}\text { Rutaceae Juss. family } \\
\text { (Citrus L. genus) }\end{array}$ & $\begin{array}{l}\downarrow A K T \text { and ERK signaling pathways, } \downarrow \text { Galectin-3 protein } \\
\text { expression }\end{array}$ & $\begin{array}{l}\text { Xu et al. } \\
(2018)\end{array}$ \\
\hline & Transcriptomics & Water extract & $\begin{array}{l}\text { Andrographis paniculata } \\
\text { (Burm.f.) Nees }\end{array}$ & $\begin{array}{l}\text { Regulation of WNT, TGF- } \beta \text {, MAPK, and ErbB signalling } \\
\text { pathways and ATP-binding cassette transporters }\end{array}$ & $\begin{array}{l}\text { Li et al. } \\
\text { (2018b) }\end{array}$ \\
\hline
\end{tabular}

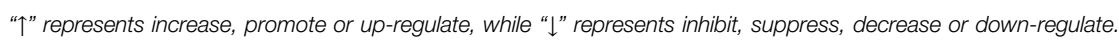

growth and induced apoptosis through a caspase-dependent mitochondrial pathway in HepG2 cells, whereas enforcing Hsp27 expression rescued these suppressive effects of TDP (Fu et al., 2012b). Dioscin extracted from Dioscorea oppositifolia L. inhibited tumour growth in diethylnitrosamine (DEN)-induced primary liver cancer rats and HCC xenograft nude mice by triggering apoptosis, autophagy, and DNA damage. The iTRAQ assay identified that the expression of TP53-inducible glycolysis and apoptosis regulator (TIGAR) was markedly decreased by dioscin, which was further verified by real-time PCR and Western blotting assays in vitro and in vivo. Knockdown of TIGAR aggravated the inhibitory effects of dioscin by increasing p53 and inhibiting the Akt/mTOR and CDK5/ATM pathways in SMMC7721 cells and a tumour xenograft nude mouse model (Mao et al., 2019). Proteomic analysis revealed that GUTK isolated from the Garcinia yunnanensis Hu markedly upregulated actin-binding protein profilin 1 (PFN1) expression. Tissue microarray data showed that a reduction in PFN1 expression was more common in advanced human HCC, which was associated with a low survival rate. Moreover, overexpression of PFN1 mimicked the effects of GUTK on decreasing the expression of tumour metastasis markers, including F-actin and other proteins involved in actin nucleation, branching and polymerization (Shen et al., 2016).
The anti-HCC mechanisms of other medicinal plants unravelled using proteomic approaches are listed in Table 3.

\section{Transcriptomics}

Triptolide, a structurally unique diterpene triepoxide extracted from Tripterygium wilfordii Hook F., induced apoptosis in multiple HCC cell lines in a p53-independent manner. A microRNA microarray identified that triptolide significantly downregulated the expression of two oncogenic miRNA clusters (miR-17-92 and miR-106b-25) in HepG2 cells and a xenograft mouse model, which subsequently upregulated the expression levels of their common target genes, including BIM, PTEN, and p21. Knockdown of these two miRNA clusters enhanced the anticancer activity of triptolide, while their overexpression protected HCC cells from triptolide-induced apoptosis. Further mechanistic studies illustrated that triptolide inhibited these two miRNA clusters by repressing the expression of $\mathrm{c}-\mathrm{Myc}$ by targeting the ERCC3 protein ( $\mathrm{Li}$ et al., 2018a). Additionally, transcriptomics approaches have gained insight into various genetic alterations underlying the anti-HCC mechanisms of baicalein isolated from Scutellariae radix (Ma et al., 2019a), Smilax glabra Roxb. water-soluble extract (She et al., 2015) and apigenin (Wang et al., 2021) (Table 3). 


\section{Metabolomics}

Compound Kushen injection (CKI) inhibited the proliferation and migration of SMMC-7721 cells in vitro by inhibiting the protein expression of MMP2, MYC and REG1A and increasing CASP3 protein expression. The ${ }^{1} \mathrm{H}-\mathrm{NMR}$ metabolomics approach validated twenty-two differential metabolites mapped to key pathways of glycometabolism and amino acid metabolism after treatment with CKI. More specifically, CKI significantly increased the content of pyruvate in the medium while decreasing the uptake of HCC-elevated glutamate in the cell, subsequently attenuating metabolic disorders in hepatoma cells (Gao et al., 2018). A metabolomic study of DEN-induced HCC rats characterized that Shuihonghuazi formula (SHHZF) augmented the uptake and utilization of linoleic acid and oleic acid and increased the content of arachidonic acid metabolites, which improved organism immunity. Moreover, SHHZF also increased the activity of phosphatidylethanolamine $\mathrm{N}$-methyltransferase (PEMT), a liver-specific enzyme that negatively regulates cancer cell proliferation, and suppressed the abnormal metabolism of bile acid. SHHZF regulated these metabolites to a normal level, which could partially explain the mechanism of the therapeutic effects of SHHZF on liver cancer (Bao et al., 2017). Ren et al. developed a novel type of nanomedicine, $\mathrm{NpRg} 3$, by conjugating $\mathrm{Fe} @ \mathrm{Fe}_{3} \mathrm{O}_{4}$ nanoparticles with ginsenoside $\mathrm{Rg} 3$. NpRg3 significantly decreased DENinduced liver tumour nodules, delayed HCC-induced ileocecal morphology, prolonged the survival of HCC mice and inhibited lung metastasis by enhancing the immune response. Metabolomics analysis in mouse serum and liver demonstrated that NpRg3 application inhibited HCC progression by increasing free fatty acids, decreasing 3 -indolepropionic acid and urea, and remodelling the unbalanced gut microbiota (Ren et al., 2020). Table 3 also summarizes other usages of metabonomics approaches in identifying metabolite changes in response to triterpenoid saponins from Anemone flaccida F. Schmidt (Han et al., 2019), Solasonine isolated from Solanum melongena L. (Jin et al., 2020), psoralen-loaded polymer lipid nanoparticles ( $\mathrm{Li}$ et al., 2021), Annona squamosa L. (Ma et al., 2019b), and Rhizoma Paridis saponins (Qiu et al., 2016).

\section{Multi-OMICS}

Zerumbone, a sesquiterpene derived from Zingiber zerumbet (L.) Roscoe ex Sm., inhibited HCC tumorigenesis by inducing cell cycle arrest and apoptosis in vitro and retarded subcutaneous and orthotopic tumour growth and lung metastasis in NSG mice. A microarray together with a human phosphoprotein array determined that zerumbone induced apoptosis in HCC cells by activating proapoptotic genes (DIABLO, CASP3, BNIP3L, DEED and PMAIP1) and inhibiting antiapoptotic gene (ERCC2 and HELLS) expression; the PI3K/AKT/mTOR and STAT3 signalling pathways were also inhibited. NMR-based metabolomics analysis showed significant suppression of ${ }^{13} \mathrm{C}_{6}$-glucose consumption and glycolytic intermediate levels (glycerol-3phosphate and 3-phosphoglycerate) in zerumbone-treated HCC cells. Further mechanistic studies validated that zerumbone deregulates the expression of glycolysis and pentose phosphate pathway genes, which may be an effective approach to suppress hepatocarcinogenesis (Wani et al., 2018).

\section{Pancreatic Cancer}

Pancreatic cancer is becoming one of the deadliest cancers, with the highest mortality worldwide because of its pathogenic latency and the lack of efficient drugs in the clinic. The overall 5-year survival rate of pancreatic cancer is lower than 5\% (McGuigan et al., 2018). OMICS, especially transcriptomics, has revealed a series of oncosuppressor gene and protooncogene alterations upon medicinal plant treatment, which has aroused increasing opportunities to find potential biomarkers and eventually concurrent pancreatic cancer (Table 4).

\section{Proteomics}

Betulinic acid (BA) derived from the Rhamnaceae, Paeoniaceae, Myrtaceae, and Betulaceae families selectively suppressed pancreatic ductal adenocarcinoma cell (PDAC) proliferation and metastasis without affecting normal pancreatic cells. A protein microarray combined with the Kaplan-Meier plotter database identified that BA upregulated VAPB, BRE and APOA1 protein expression, which may contribute to longer survival times in PDAC patients. Interestingly, BA-downregulated proteins (TACO1, RNF167, POLRMT, and DDX49) were associated with mitochondrial respiratory chain complex I activity, which partially explained the anti-pancreatic mechanisms of BA (Chiu et al., 2021). In addition, a large-scale labelfree comparative proteomic approach uncovered multiple proteins, including CUL5, IL33, GPS1 and DUSP4, that are responsible for the anti-pancreatic cancer effect of sanguinarine found in plants of Papaveraceae family. Further qRT-PCR and immunoblot analyses validated that DUSP4 was remarkably upregulated following sanguinarine treatment, which is a possible tumor suppressor that negatively regulates ERK, JNK and MAPK (Singh et al., 2015).

\section{Transcriptomics}

Intragastric administration of a mixed powder of traditional Chinese medicine called Babao Dan (BBD) significantly decreased volumes and weights in PDAC mouse models. High-throughput RNA sequencing identified 638 upregulated genes (including tumour suppressor genes such as MTUS1, PDGFB, SOD3, and UCHL1) and 259 downregulated genes (including oncogenes such as CDK15 and MYBL1) in response to BBD. These altered genes were associated with BBD-inhibited cancer-related pathways (MAPK cascade and Wnt signalling pathway) and BBDelevated metabolic activities (steroid hormone biosynthesis and adipocyte lipolysis regulation) (Song et al., 2020). Marigold SFE, a supercritical $\mathrm{CO}_{2}$ extract from Calendula officinalis L., induced autophagic cell death in MiaPaca-2 pancreatic cancer cells by diminishing mitochondrial respiration and aerobic glycolysis. A comparative gene expression microarray identified that marigold SFE treatment upregulated the expression of bone 
morphogenetic protein-8B (BMP8B), which led to energetic catastrophe and subsequently induced autophagic cell death. More importantly, silencing $B M P 8 B$ reversed the inhibition of mitochondrial oxidative phosphorylation caused by marigold SFE and alleviated ER stress and CHOP expression (Gómez de Cedrón et al., 2019). Consistently, RNA sequencing confirmed several transcriptional changes in response to piperlongumine isolated from long peppers in MiaPaca-2 cells, which were associated with oxidative stress and ER stress (Dhillon et al., 2016). Microarray assays also help identify various alterations in tumour suppressor genes and proto-oncogene expression after treatment of medicinal plants, such as Abisil extracted from Abies sibirica Ledeb. (Kudryavtseva et al., 2016) and Emodin isolated from Rheum palmatum L. (Zhang et al., 2015) (Table 4). For example, the tumour suppressor gene candidate HTRA3 was significantly augmented after treatment with paeoniflorin (PF) extracted from Paeonia lactiflora Pall(Li et al., 2017).

\section{Multi-OMICS}

Berberine (BBR), an isoquinoline alkaloid widely found in Chinese medicinal plants, suppressed the viability and metastasis of pancreatic cancer cells. A precision-targeted metabolome assay demonstrated that BBR significantly disturbed the energy metabolism of pancreatic cancer cells by damaging mitochondrial structure and affecting tricarboxylic acid cycle activity by influencing citrate metabolism and transportation. Further RNA sequencing revealed that BBR blocked the biosynthesis of fatty acids by mediating ACLY, ACO1 and SLC25A1. Moreover, BBR decreased the expression of the oncogene KRAS and increased the expression of the tumour suppressor gene CDKN2A (Liu et al., 2020).

\section{Oesophageal Cancers}

Oesophageal squamous cell carcinoma (ESCC) is the predominant histological subtype and accounts for the highest incidence of oesophageal cancer cases in China (Table 5). Synephrine, a natural phenolic compound isolated from the leaves of citrus trees, inhibited ESCC proliferation, migration and invasion and enhanced the sensitivity of ESCC cells to fluorouracil (5-FU). Quantitative proteomics identified that synephrine exhibited anticancer effects through inactivating AKT and ERK pathways by downregulating the protein expression of Galectin-3, which was further validated by western blot and qRT-PCR in ESCC cells and tumour xenografts in nude mice (Xu et al., 2018). Gene expression microarray analysis revealed that the water extract of Andrographis paniculata (Burm.f.) Nees (APW) exhibited anticancer and antimetastatic activities on ESCC cells by regulating WNT, TGF$\beta, \mathrm{MAPK}$, and ErbB signalling pathways and ATP-binding cassette transporters ( $\mathrm{Li}$ et al., 2018b).

\section{DISCUSSION AND PROSPECTS}

Plants are a treasure trove for the research and development of new drugs, with approximately one-quarter of the world's commonly used drugs now being developed from plant ingredients. However, there are still numerous agents that failed to obtain approval under clinical trials due to their unclear active ingredients and mechanisms. Therefore, multiple OMIC approaches have prompted the development of anticancer agents to an unprecedented level, especially those derived from medicinal plants. Over the past decades, advances in OMICS technology have made great efforts to identify molecular and cellular mechanisms contributing to the development and progression of cancer. To further facilitate the research and discovery of anticancer drugs in medicinal plants, we suggest integrating multiple OMICS analyses, introducing OMICS in precision medicine, and applying single-cell multi-OMICS in research on tumour heterogeneity.

\section{Integration of Multi-OMICS Approaches in Cancer Research}

Single OMICS approaches, such as DNA-seq, microarray and iTRAQ, have revealed intricate anti-GI cancer mechanisms of medicinal plants in different dimensions (such as the gene, RNA, and protein levels) (Chakraborty et al., 2018). However, depicting the anticancer pharmacological actions of medicinal plants at a unidirectional level relying on individual OMICS data is insufficient for discovering the whole profiles of mechanisms. To better understand the cancer-host interactions and key molecular targets of natural anticancer compounds from a systematic and holistic perspective, multidimensional approaches are required and have become a vital step in cancer research. For instance, by integrating quantitative proteomics and transcriptomics, both transcriptional and posttranscriptional genes have been identified in TIIAtreated gastric cancer cells, providing comprehensive and detailed insight into mechanistic studies (Lin et al., 2015). Additionally, combining transcriptomic and metabolomic datasets uncovered a strong correlation between energy metabolism and fatty acid biosynthesis-related genes after BBR treatment (Liu et al., 2020). The emergence of multiOMICS technologies has greatly impacted the cancer research landscape, bridged the gap between the molecular signatures and phenotypic characteristics of cancer and enabled the identification of therapeutic targets and the development of new drugs in medicinal plants.

\section{Introduction of OMICS in Precision Medicine}

The complexity of cancers and diversity of patients have increased the requirements for precise and personalized medical treatments. Precision medicine is defined as custom-made healthcare of individual patient that is tailored on the basis of genetic, phenotypic, or psychosocial characteristics. Precision medicine that addresses cancer is referred to as "precision oncology," which seeks to determine 
tumour-driving networks and to design a personalized therapy in particular patient's tumour. Numerous OMICS technologies have provided essential information for precision oncology in diagnosing patients, predicting risk, and assessing whether specific treatments are suitable for certain cancer patients. Starting from the field of genomics, next-generation whole-exome and whole-genome sequencing data have largely facilitated the identification of cancerspecific mutations, analysis of chromosomal rearrangements and copy number variations in individual tumours. Recent clinical applications of genome-wide association studies are focusing on drug discovery and repositioning, cancer prognostication, and risk modelling (Sud et al., 2017). Epigenomics merits decimating tumour cells from normal cells and differences within tumour cells during disease progression and drug treatment. For example, the DNA methylation status of the MGMT promoter is currently utilized to determine whether therapeutic agents are effective in glioblastoma treatment (Hegi et al., 2005). Additionally, a majority of metabolomics data have focused on the analysis of plasma or serum samples from patients during diagnosis, which could identify tumour-specific biomarkers without invasive tumour biopsy (Olivier et al., 2019). In particular, some putative metabolic biomarkers have been identified for early-stage detection of colorectal cancer, such as unsaturated free fatty acids (Zhang et al., 2016). Several studies have utilized proteomic approaches to identify cancer-specific biomarkers; however, their promotion of clinical benefit is limited because protein function is regulated by a myriad of mechanisms (Swiatly et al., 2018; Yanovich et al., 2018).

However, it is worth noting that the occurrence of cancer does not necessarily exhibit genetic alterations, nor is it always reflected in metabolite profiles. Therefore, false-negative results from OMICS may lead to the missed diagnosis of cancers, while false-positive results, especially those previously reported pathogenic markers that were actually from benign tissues, may lead to misdiagnosis (Andreasen et al., 2013). For example, nonsynonymous $B A R D 1$ gene variants were previously reported to be associated with increased breast cancer risk. However, later studies found that three previously reported pathogenic variants are benign polymorphisms in the Australian population, indicating that BARD1 is not accurate enough to represent the highpenetrance susceptibility gene of breast cancer (Gorringe et al., 2008). To avoid these mistakes, large, diverse, and standardized datasets should be established to provide comprehensive profiles of cancer patients. DECIPHER, the first web-accessible database that linked disease phenotype with pathogenic sequence and numbers of variants, was established in 2004 (Swaminathan et al., 2012). The Cancer Genome Atlas (TCGA) characterizes detailed OMICS and clinical data on approximately 85,000 cases of 36 kinds of cancer types (Shah et al., 2016). CancerLinQ, a quality measurement and reporting system raised by the American Society of Clinical Oncology (ASCO), was established to collect bioinformation from large numbers of patients with cancer (Shah et al., 2016). The significance of these standardized datasets not only improves individual patient treatment but also contributes to the discovery of disease and drug mechanisms for the medical community (Schilsky et al., 2014).

\section{Application of Single-Cell Multi-OMICS in Research of Tumour Heterogeneity}

Tumour heterogeneity, including intertumoural heterogeneity (heterogeneity between different tumour types) and intratumoural heterogeneity (heterogeneity within individual tumours), plays essential roles in tumour progression, metastasis and chemoradiotherapy resistance. Previously, high-throughput sequencing techniques have been employed to uncover heterogeneity by profiling genomes, transcriptomes, proteomes and epigenomes of the cellular components. For example, an integrated genome-wide DNA copy number array and a gene expression array were used to classify distinct glioblastoma subtypes of patient tumour tissues (Sottoriva et al., 2013). Exome sequencing transcriptomics was performed to detect both good and poor prognosis gene expression signatures in different regions of the whole primary renal carcinoma (Gerlinger et al., 2012). However, the limitations of these techniques on investigating tumour heterogeneity are obvious since these procedures usually detect the average signals of mixed cell populations rather than individual cells. In this case, single-cell sequencing technologies exhibit great advantages in profiling comprehensive molecular features of tumour tissues (Hoppe et al., 2014).

Single-cell multi-OMICS technologies could characterize hybrid states of cancer cells within a tumour. Using single-cell RNA sequencing (scRNA-seq), different kinds of cells with the potential to regulate the tumour microenvironment have been identified in various cancers, such as epithelial/mesenchymal cells, immune cells and endothelial cells (Pan and Jia, 2021). In addition, single-cell techniques can distinguish cancer cell subpopulations with different biological characteristics. For instance, scRNA-seq revealed several cancer cell subpopulations with differential proliferative and migratory potentials in PDAC, indicating the high intertumour heterogeneity of PDAC (Peng et al., 2019). Quiescent cancer cells (QCCs), a batch of cancer cells among heterogeneous cancer cell populations, temporarily reside in the $\mathrm{G}_{0} / \mathrm{G}_{1}$ phase and are naturally refractory to chemotherapeutic drugs that depend on proliferative mechanisms (Nik Nabil et al., 2021). In addition, QCCs represent a clinically asymptomatic form of dormancy that have the ability to revive from an inert state to rapidly grow, eventually leading to cancer recurrence. As a result, isolation and functional study of QCCs by single-cell multi-OMICS techniques will be a powerful tool to develop therapeutic strategies targeting dormant cancer cells to prevent recurrence (Davis et al., 2019). Studies have discovered active compounds with cytotoxicity against QCCs from herbal medicine (such as GUTK isolated from the Garcinia genus and safranal from Crocus sativus L.) (Xi et al., 2016; Jiang et al., 2020). Drug resistance is another consequence of tumour heterogeneity, and great progress has been made by utilizing multiple single-cell sequencing methods to uncover drug resistance mechanisms. For instance, the intratumoural heterogeneity and drug-refractory subclones of breast cancer patients were analysed by single-cell transcriptomic analysis after years of chemotherapy treatment. Interestingly, mesenchymal and growth factor signalling 
pathways, including the epithelial-mesenchymal transition pathway and receptor tyrosine kinases, were enhanced, while antigen presentation and tumour necrosis factor alpha (TNF- $\alpha$ ) signalling were reduced (Brady et al., 2018).

In conclusion, the development of high-throughput sequencing technologies has brought unprecedented opportunities in the field of OMICS. With the optimization and maturity of various technologies, the application of multi-OMICS will become more extensive, and it will play a vital role in advancing the progress of anticancer drug research in medicinal plants.

\section{AUTHOR CONTRIBUTIONS}

Conceptualization, $\mathrm{RD}$ and $\mathrm{ZX}$; validation, $\mathrm{ZX}$ and $\mathrm{HX}$; investigation, $\mathrm{RD}$ and $\mathrm{ML}$; resources, $\mathrm{RD}$ and $\mathrm{ML}$;

\section{REFERENCES}

Abdul-Latif, M., Townsend, K., Dearman, C., Shiu, K.-K., and Khan, K. (2020). Immunotherapy in Gastrointestinal Cancer: The Current Scenario and Future Perspectives. Cancer Treat. Rev. 88, 102030. doi:10.1016/j.ctrv.2020.102030

Aebersold, R., and Mann, M. (2003). Mass Spectrometry-Based Proteomics. Nature 422 (6928), 198-207. doi:10.1038/nature01511

Andreasen, C., Nielsen, J. B., Refsgaard, L., Holst, A. G., Christensen, A. H., Andreasen, L., et al. (2013). New Population-Based Exome Data Are Questioning the Pathogenicity of Previously Cardiomyopathy-Associated Genetic Variants. Eur. J. Hum. Genet. 21 (9), 918-928. doi:10.1038/ejhg. 2012.283

Baltgalvis, K. A., Berger, F. G., Peña, M. M., Davis, J. M., and Carson, J. A. (2009). The Interaction of a High-Fat Diet and Regular Moderate Intensity Exercise on Intestinal Polyp Development in Apc Min/+ Mice. Cancer Prev. Res. (Phila) 2 (7), 641-649. doi:10.1158/1940-6207.CAPR-09-0017

Bao, Y., Wang, S., Yang, X., Li, T., Xia, Y., and Meng, X. (2017). Metabolomic Study of the Intervention Effects of Shuihonghuazi Formula, a Traditional Chinese Medicinal Formulae, on Hepatocellular Carcinoma (HCC) Rats Using Performance HPLC/ESI-TOF-MS. J. Ethnopharmacol 198, 468-478. doi:10. 1016/j.jep.2017.01.029

Baxter, B. A., Oppel, R. C., and Ryan, E. P. (2018). Navy Beans Impact the Stool Metabolome and Metabolic Pathways for Colon Health in Cancer Survivors. Nutrients 11 (1). doi:10.3390/nu11010028

Bednár, M. (2000). DNA Microarray Technology and Application. Med. Sci. Monit. 6 (4), 796-800.

Brady, S. W., McQuerry, J. A., Qiao, Y., Piccolo, S. R., Shrestha, G., Jenkins, D. F., et al. (2018). Publisher Correction: Combating Subclonal Evolution of Resistant Cancer Phenotypes. Nat. Commun. 9 (1), 572. doi:10.1038/s41467-017-02383-6

Bray, F., Ferlay, J., Soerjomataram, I., Siegel, R. L., Torre, L. A., and Jemal, A. (2018). Global Cancer Statistics 2018: GLOBOCAN Estimates of Incidence and Mortality Worldwide for 36 Cancers in 185 Countries. CA Cancer J. Clin. 68 (6), 394-424. doi:10.3322/caac.21492

Bucio-Noble, D., Kautto, L., Krisp, C., Ball, M. S., and Molloy, M. P. (2018). Polyphenol Extracts from Dried Sugarcane Inhibit Inflammatory Mediators in an in vitro colon Cancer Model. J. Proteomics 177, 1-10. doi:10.1016/j.jprot. 2018.02.009

Budisan, L., Gulei, D., Jurj, A., Braicu, C., Zanoaga, O., Cojocneanu, R., et al. (2019). Inhibitory Effect of CAPE and Kaempferol in Colon Cancer Cell Lines-Possible Implications in New Therapeutic Strategies. Int. J. Mol. Sci. 20 (5). doi:10.3390/ ijms20051199

Cai, X. Z., Huang, W. Y., Qiao, Y., Du, S. Y., Chen, Y., Chen, D., et al. (2013). Inhibitory Effects of Curcumin on Gastric Cancer Cells: a Proteomic Study of Molecular Targets. Phytomedicine 20 (6), 495-505. doi:10.1016/j.phymed.2012. 12.007

Chai, Y., and Zhao, M. (2017). iTRAQ-Based Quantitative Proteomic Analysis of the Inhibitory Effects of Polysaccharides from Viscum Coloratum writing-original draft preparation, $\mathrm{RD}$ and $\mathrm{ML}$; writing-review and editing, RD, ML, YL, XX, and ZX; visualization, $\mathrm{YL}$ and $\mathrm{XX}$; supervision, $\mathrm{ZX}$ and $\mathrm{HX}$; project administration, ZX and HX; funding acquisition, ZX and HX. All authors have read and agreed to the published version of the manuscript.

\section{FUNDING}

This work is supported by National Natural Science Foundation of China (No. 81803571); Project funded by China Postdoctoral Science Foundation (No. 2020TQ0198) and Development Program of Guangdong Province (Grant No. 2020B1111110003).

(Kom.) Nakai on HepG2 Cells. Sci. Rep. 7 (1), 4596. doi:10.1038/ s41598-017-04417-x

Chakraborty, S., Hosen, M. I., Ahmed, M., and Shekhar, H. U. (2018). Onco-MultiOMICS Approach: A New Frontier in Cancer Research. Biomed. Res. Int. 2018, 9836256. doi:10.1155/2018/9836256

Chen, J. F., Tsai, Y. T., Lai, Y. H., Lin, C. C., Chou, H. C., Kuo, W. H., et al. (2020). Proteomic Analysis of Antrodia Cinnamomea-Induced ER Stress in Liver Cancer Cells. J. Pharm. Biomed. Anal. 187, 113142. doi:10.1016/j.jpba.2020.113142

Chiu, C. F., Chang, H. Y., Huang, C. Y., Mau, C. Z., Kuo, T. T., Lee, H. C., et al. (2021). Betulinic Acid Affects the Energy-Related Proteomic Profiling in Pancreatic Ductal Adenocarcinoma Cells. Molecules 26 (9). doi:10.3390/ molecules26092482

Chu, Z., Shi, X., Chen, G., He, X., Qian, Y., Wang, H., et al. (2021). COE Inhibits Vasculogenic Mimicry by Targeting EphA2 in Hepatocellular Carcinoma, a Research Based on Proteomics Analysis. Front. Pharmacol. 12, 619732. doi:10. 3389/fphar.2021.619732

Davis, J. E., Jr., Kirk, J., Ji, Y., and Tang, D. G. (2019). Tumor Dormancy and SlowCycling Cancer Cells. Adv. Exp. Med. Biol. 1164, 199-206. doi:10.1007/978-3030-22254-3_15

Dhillon, H., Mamidi, S., McClean, P., and Reindl, K. M. (2016). Transcriptome Analysis of Piperlongumine-Treated Human Pancreatic Cancer Cells Reveals Involvement of Oxidative Stress and Endoplasmic Reticulum Stress Pathways. J. Med. Food 19 (6), 578-585. doi:10.1089/jmf.2015.0152

Dong, X. Z., Song, Y., Lu, Y. P., Hu, Y., Liu, P., and Zhang, L. (2019). Sanguinarine Inhibits the Proliferation of BGC-823 Gastric Cancer Cells via Regulating miR96-5p/miR-29c-3p and the MAPK/JNK Signaling Pathway. J. Nat. Med. 73 (4), 777-788. doi:10.1007/s11418-019-01330-7

Fan, D., Liu, C., Li, L., Lu, C., Zhao, N., Shu, J., et al. (2020). Deciphering Antitumor Mechanism of Pien Tze Huang in Mice of Hepatocellular Carcinoma Based on Proteomics. J. Immunol. Res. 2020, 4876251. doi:10.1155/2020/4876251

Fang, X., Tan, T., Gao, B., Zhao, Y., Liu, T., and Xia, Q. (2020). Germacrone Regulates HBXIP-Mediated Cell Cycle, Apoptosis and Promotes the Formation of Autophagosomes to Inhibit the Proliferation of Gastric Cancer Cells. Front. Oncol. 10, 537322. doi:10.3389/fonc.2020.537322

Fu, W. M., Zhang, J. F., Wang, H., Tan, H. S., Wang, W. M., Chen, S. C., et al. (2012). Apoptosis Induced by 1,3,6,7-tetrahydroxyxanthone in Hepatocellular Carcinoma and Proteomic Analysis. Apoptosis 17 (8), 842-851. doi:10.1007/ s10495-012-0729-y

Fu, W. M., Zhang, J. F., Wang, H., Xi, Z. C., Wang, W. M., Zhuang, P., et al. (2012). Heat Shock Protein 27 Mediates the Effect of 1,3,5-Trihydroxy-13,13Dimethyl-2h-Pyran [7,6-b] Xanthone on Mitochondrial Apoptosis in Hepatocellular Carcinoma. J. Proteomics 75 (15), 4833-4843. doi:10.1016/j. jprot.2012.05.032

Gagnière, J., Raisch, J., Veziant, J., Barnich, N., Bonnet, R., Buc, E., et al. (2016). Gut Microbiota Imbalance and Colorectal Cancer. World J. Gastroenterol. 22 (2), 501-518. doi:10.3748/wjg.v22.i2.501

Gao, L., Wang, K. X., Zhou, Y. Z., Fang, J. S., Qin, X. M., and Du, G. H. (2018). Uncovering the Anticancer Mechanism of Compound Kushen Injection against 
HCC by Integrating Quantitative Analysis, Network Analysis and Experimental Validation. Sci. Rep. 8 (1), 624. doi:10.1038/s41598-017-18325-7

Gao, Y., Su, Y., Qu, L., Xu, S., Meng, L., Cai, S. Q., et al. (2011). Mitochondrial Apoptosis Contributes to the Anti-cancer Effect of Smilax Glabra Roxb. Toxicol. Lett. 207 (2), 112-120. doi:10.1016/j.toxlet.2011.08.024

Gerlinger, M., Rowan, A. J., Horswell, S., Math, M., Larkin, J., Endesfelder, D., et al. (2012). Intratumor Heterogeneity and Branched Evolution Revealed by Multiregion Sequencing. N. Engl. J. Med. 366 (10), 883-892. doi:10.1056/ NEJMoa1113205

Gniechwitz, D., Reichardt, N., Blaut, M., Steinhart, H., and Bunzel, M. (2007). Dietary Fiber from Coffee Beverage: Degradation by Human Fecal Microbiota. J. Agric. Food Chem. 55 (17), 6989-6996. doi:10.1021/jf070646b

Gómez de Cedrón, M., Mouhid, L., García-Carrascosa, E., Fornari, T., Reglero, G., and Ramírez de Molina, A. (2019). Marigold Supercritical Extract as Potential Co-adjuvant in Pancreatic Cancer: The Energetic Catastrophe Induced via BMP8B Ends up with Autophagy-Induced Cell Death. Front. Bioeng. Biotechnol. 7, 455. doi:10.3389/fbioe.2019.00455

Gorringe, K. L., Choong, D. Y., Visvader, J. E., Lindeman, G. J., and Campbell, I. G. (2008). BARD1 Variants Are Not Associated with Breast Cancer Risk in Australian Familial Breast Cancer. Breast Cancer Res. Treat. 111 (3), 505-509. doi:10.1007/s10549-007-9799-x

Graziani, V., Scognamiglio, M., Belli, V., Esposito, A., D’Abrosca, B., Chambery, A., et al. (2018). Metabolomic Approach for a Rapid Identification of Natural Products with Cytotoxic Activity against Human Colorectal Cancer Cells. Sci. Rep. 8 (1), 5309. doi:10.1038/s41598-018-23704-9

Guo, Y., Wu, R., Gaspar, J. M., Sargsyan, D., Su, Z. Y., Zhang, C., et al. (2018). DNA Methylome and Transcriptome Alterations and Cancer Prevention by Curcumin in Colitis-Accelerated colon Cancer in Mice. Carcinogenesis 39 (5), 669-680. doi:10.1093/carcin/bgy043

Han, L., Yao, S., Cao, S., Mo, G., Li, J., Cao, Y., et al. (2019). Triterpenoid Saponins from Anemone Flaccida Suppress Tumor Cell Proliferation by Regulating MAPK, PD1/PDL1, and STAT3 Signaling Pathways and Altering Cancer Metabolism. Onco Targets Ther. 12, 10917-10930. doi:10.2147/OTT. S212666

Hegi, M. E., Diserens, A. C., Gorlia, T., Hamou, M. F., de Tribolet, N., Weller, M., et al. (2005). MGMT Gene Silencing and Benefit from Temozolomide in Glioblastoma. N. Engl. J. Med. 352 (10), 997-1003. doi:10.1056/NEJMoa043331

Hernández-Balmaseda, I., Guerra, I. R., Declerck, K., Herrera Isidrón, J. A., PérezNovo, C., Van Camp, G., et al. (2021). Marine Seagrass Extract of Thalassia Testudinum Suppresses Colorectal Tumor Growth, Motility and Angiogenesis by Autophagic Stress and Immunogenic Cell Death Pathways. Mar. Drugs 19 (2), 52. doi:10.3390/md19020052

Hoppe, P. S., Coutu, D. L., and Schroeder, T. (2014). Single-cell Technologies Sharpen up Mammalian Stem Cell Research. Nat. Cell Biol 16 (10), 919-927. doi:10.1038/ncb3042

Hou, C., Chu, H. J., Dai, X. J., Wu, Y. Q., He, Z. F., Yu, Y. W., et al. (2021). Metabolomic Study on the Therapeutic Effect of the Jianpi Yangzheng Xiaozheng Decoction on Gastric Cancer Treated with Chemotherapy Based on GC-TOFMS Analysis. Evid. Based Complement. Alternat Med. 2021, 8832996. doi:10.1155/2021/8832996

Hu, X. Q., Sun, Y., Lau, E., Zhao, M., and Su, S. B. (2016). Advances in Synergistic Combinations of Chinese Herbal Medicine for the Treatment of Cancer. Curr. Cancer Drug Targets 16 (4), 346-356. doi:10.2174/ 1568009616666151207105851

Ji, X., Hou, C., Zhang, X., Han, L., Yin, S., Peng, Q., et al. (2019). Microbiomemetabolomic Analysis of the Impact of Zizyphus Jujuba Cv. Muzao Polysaccharides Consumption on Colorectal Cancer Mice Fecal Microbiota and Metabolites. Int. J. Biol. Macromol 131, 1067-1076. doi:10.1016/j.ijbiomac. 2019.03.175

Jiang, X., Li, Y., Feng, J. L., Nik Nabil, W. N., Wu, R., Lu, Y., et al. (2020). Safrana L Prevents Prostate Cancer Recurrence by Blocking the Re-activation of Quiescent Cancer Cells via Downregulation of S-phase Kinase-Associated Protein 2. Front Cell Dev Biol 8, 598620. doi:10.3389/fcell.2020.598620

Jin, M., Shi, C., Li, T., Wu, Y., Hu, C., and Huang, G. (2020). Solasonine Promotes Ferroptosis of Hepatoma Carcinoma Cells via Glutathione Peroxidase 4induced Destruction of the Glutathione Redox System. Biomed. Pharmacother. 129, 110282. doi:10.1016/j.biopha.2020.110282
Kamimura, M., Sasaki, A., Watanabe, S., Tanaka, S., Fukukawa, A., Takeda, K., et al. (2020). Chemical and Molecular Bases of Dome Formation in Human Colorectal Cancer Cells Mediated by sulphur Compounds from Cucumis Melo Var. Conomon. FEBS Open Bio 10 (12), 2640-2655. doi:10.1002/22115463.13001

Kim, D. A., Jeon, Y. K., and Nam, M. J. (2012). Galangin Induces Apoptosis in Gastric Cancer Cells via Regulation of Ubiquitin Carboxy-Terminal Hydrolase Isozyme L1 and Glutathione S-Transferase P. Food Chem. Toxicol. 50 (3-4), 684-688. doi:10.1016/j.fct.2011.11.039

Kim, S. H., Jin, H., Meng, R. Y., Kim, D. Y., Liu, Y. C., Chai, O. H., et al. (2019). Activating Hippo Pathway via Rassf1 by Ursolic Acid Suppresses the Tumorigenesis of Gastric Cancer. Int. J. Mol. Sci. 20 (19). doi:10.3390/ ijms20194709

Koçak, E., Çelebier, M., Haznedaroglu, I. C., and Altınöz, S. (2019). Analysis of the Antiproliferative Effect of Ankaferd Hemostat on Caco-2 Colon Cancer Cells via LC/MS Shotgun Proteomics Approach. Biomed. Res. Int. 2019, 5268031. doi:10.1155/2019/5268031

Kudryavtseva, A., Krasnov, G., Lipatova, A., Alekseev, B., Maganova, F., Shaposhnikov, M., et al. (2016). Effects of Abies Sibirica Terpenes on Cancer- and Aging-Associated Pathways in Human Cells. Oncotarget 7 (50), 83744-83754. doi:10.18632/oncotarget.13467

Kuntz, S., Krieghoff-Henning, E., Kather, J. N., Jutzi, T., Höhn, J., Kiehl, L., et al. (2021). Gastrointestinal Cancer Classification and Prognostication from Histology Using Deep Learning: Systematic Review. Eur. J. Cancer 155, 200-215. doi:10.1016/j.ejca.2021.07.012

Lee, H. J., Venkatarame Gowda Saralamma, V., Kim, S. M., Ha, S. E., Vetrivel, P., Kim, E. H., et al. (2018). Comparative Proteomic Profiling of Tumor-Associated Proteins in Human Gastric Cancer Cells Treated with Pectolinarigenin. Nutrients 10 (11). doi:10.3390/nu10111596

Leo, R., Therachiyil, L., Siveen, S. K., Uddin, S., Kulinski, M., Buddenkotte, J., et al. (2019). Protein Expression Profiling Identifies Key Proteins and Pathways Involved in Growth Inhibitory Effects Exerted by Guggulsterone in Human Colorectal Cancer Cells. Cancers (Basel) 11 (10). doi:10.3390/cancers11101478

Li, L., Yue, G. G., Lee, J. K., Wong, E. C., Fung, K. P., Yu, J., et al. (2018). Gene Expression Profiling Reveals the Plausible Mechanisms Underlying the Antitumor and Antimetastasis Effects of Andrographis Paniculata in Esophageal Cancer. Phytother Res. 32 (7), 1388-1396. doi:10.1002/ptr.6074

Li, L., Zhao, L. M., Dai, S. L., Cui, W. X., Lv, H. L., Chen, L., et al. (2016). Periplocin Extracted from Cortex Periplocae Induced Apoptosis of Gastric Cancer Cells via the ERK1/2-EGR1 Pathway. Cell Physiol Biochem 38 (5), 1939-1951. doi:10. $1159 / 000445555$

Li, L., Zou, T., Liang, M., Mezhuev, Y., Tsatsakis, A. M., Đorđević, A. B., et al. (2021). Screening of Metabolites in the Treatment of Liver Cancer Xenografts HepG2/ADR by Psoralen-Loaded Lipid Nanoparticles. Eur. J. Pharmaceutics Biopharmaceutics 165, 337-344. doi:10.1016/j.ejpb.2021.05.025

Li, S. G., Shi, Q. W., Yuan, L. Y., Qin, L. P., Wang, Y., Miao, Y. Q., et al. (2018). C-Myc-dependent Repression of Two Oncogenic miRNA Clusters Contributes to Triptolide-Induced Cell Death in Hepatocellular Carcinoma Cells. J. Exp. Clin. Cancer Res. 37 (1), 51. doi:10.1186/s13046-018-0698-2

Li, Y., Gong, L., Qi, R., Sun, Q., Xia, X., He, H., et al. (2017). Paeoniflorin Suppresses Pancreatic Cancer Cell Growth by Upregulating HTRA3 Expression. Drug Des. Devel Ther. 11, 2481-2491. doi:10.2147/DDDT.S134518

Lichtenstern, C. R., Ngu, R. K., Shalapour, S., and Karin, M. (2020). Immunotherapy, Inflammation and Colorectal Cancer. Cells 9 (3), 618. doi: $10.3390 /$ cells 9030618

Lin, L. L., Hsia, C. R., Hsu, C. L., Huang, H. C., and Juan, H. F. (2015). Integrating Transcriptomics and Proteomics to Show that Tanshinone IIA Suppresses Cell Growth by Blocking Glucose Metabolism in Gastric Cancer Cells. BMC genomics 16 (1), 41-17. doi:10.1186/s12864-015-1230-0

Liu, J., Luo, X., Guo, R., Jing, W., and Lu, H. (2020). Cell Metabolomics Reveals Berberine-Inhibited Pancreatic Cancer Cell Viability and Metastasis by Regulating Citrate Metabolism. J. Proteome Res. 19 (9), 3825-3836. doi:10. 1021/acs.jproteome.0c00394

Liu, J. S., He, S. C., Zhang, Z. L., Chen, R., Fan, L., Qiu, G. L., et al. (2014). Anticancer Effects of $\beta$-elemene in Gastric Cancer Cells and its Potential Underlying Proteins: a Proteomic Study. Oncol. Rep. 32 (6), 2635-2647. doi:10.3892/or.2014.3490 
Ma, C., Xu, T., Sun, X., Zhang, S., Liu, S., Fan, S., et al. (2019). Network Pharmacology and Bioinformatics Approach Reveals the Therapeutic Mechanism of Action of Baicalein in Hepatocellular Carcinoma. Evid. Based Complement. Alternat Med. 2019, 7518374. doi:10.1155/2019/7518374

Ma, C., Yan, X., Yin, G., Wang, Y., Hu, S., Xia, W., et al. (2019). Non-targeted Metabolomic Analysis on Multidrug Resistance Hepatocellular Carcinoma Cell and Reversal Effect of Annonaceous Acetogenins. J. Pharm. Biomed. Anal. 164, 489-495. doi:10.1016/j.jpba.2018.10.037

Mao, Q., Zhang, P. H., Yang, J., Xu, J. D., Kong, M., Shen, H., et al. (2016). iTRAQBased Proteomic Analysis of Ginsenoside F2 on Human Gastric Carcinoma Cells SGC7901. Evid. Based Complement. Alternat Med. 2016, 2635483. doi:10. $1155 / 2016 / 2635483$

Mao, Z., Han, X., Chen, D., Xu, Y., Xu, L., Yin, L., et al. (2019). Potent Effects of Dioscin against Hepatocellular Carcinoma through Regulating TP53Induced Glycolysis and Apoptosis Regulator (TIGAR)-mediated Apoptosis, Autophagy, and DNA Damage. Br. J. Pharmacol. 176 (7), 919-937. doi:10.1111/bph.14594

McGuigan, A., Kelly, P., Turkington, R. C., Jones, C., Coleman, H. G., and McCain, R. S. (2018). Pancreatic Cancer: A Review of Clinical Diagnosis, Epidemiology, Treatment and Outcomes. World J. Gastroenterol. 24 (43), 4846-4861. doi:10. 3748/wjg.v24.i43.4846

Mekhail, T. M., and Markman, M. (2002). Paclitaxel in Cancer Therapy. Expert Opin. Pharmacother. 3 (6), 755-766. doi:10.1517/14656566.3.6.755

Nicora, G., Vitali, F., Dagliati, A., Geifman, N., and Bellazzi, R. (2020). Integrated Multi-Omics Analyses in Oncology: A Review of Machine Learning Methods and Tools. Front. Oncol. 10, 1030. doi:10.3389/fonc.2020.01030

Nie, S., Zhao, Y., Qiu, X., Wang, W., Yao, Y., Yi, M., et al. (2019). Metabolomic Study on Nude Mice Models of Gastric Cancer Treated with Modified Si Jun Zi Tang via HILIC UHPLC-Q-TOF/MS Analysis. Evid. Based Complement. Alternat Med. 2019, 3817879. doi:10.1155/2019/3817879

Nik Nabil, W. N., Xi, Z., Song, Z., Jin, L., Zhang, X. D., Zhou, H., et al. (2021). Towards a Framework for Better Understanding of Quiescent Cancer Cells. Cells 10 (3). doi:10.3390/cells10030562

Olivier, M., Asmis, R., Hawkins, G. A., Howard, T. D., and Cox, L. A. (2019). The Need for Multi-Omics Biomarker Signatures in Precision Medicine. Int. J. Mol. Sci. 20 (19). doi:10.3390/ijms20194781

Pan, D., and Jia, D. (2021). Application of Single-Cell Multi-Omics in Dissecting Cancer Cell Plasticity and Tumor Heterogeneity. Front. Mol. Biosci. 8, 757024. doi:10.3389/fmolb.2021.757024

Peng, J., Sun, B. F., Chen, C. Y., Zhou, J. Y., Chen, Y. S., Chen, H., et al. (2019). Author Correction: Single-Cell RNA-Seq Highlights Intra-tumoral Heterogeneity and Malignant Progression in Pancreatic Ductal Adenocarcinoma. Cell Res 29 (9), 777. doi:10.1038/s41422-019-0212-1

Phillips, K. A. (2018). Assessing the Value of Next-Generation Sequencing Technologies: An Introduction. Value Health 21 (9), 1031-1032. doi:10. 1016/j.jval.2018.06.012

Qiu, P., Man, S., Yang, H., Fan, W., Yu, P., and Gao, W. (2016). Utilization of Metabonomics to Identify Serum Biomarkers in Murine H22 Hepatocarcinoma and Deduce Antitumor Mechanism of Rhizoma Paridis Saponins. Chem. Biol. Interact 256, 55-63. doi:10.1016/j.cbi.2016.06.026

Ren, Z., Chen, X., Hong, L., Zhao, X., Cui, G., Li, A., et al. (2020). Nanoparticle Conjugation of Ginsenoside Rg3 Inhibits Hepatocellular Carcinoma Development and Metastasis. Small 16 (2), e1905233. doi:10.1002/smll. 201905233

Rogler, G. (2014). Chronic Ulcerative Colitis and Colorectal Cancer. Cancer Lett. 345 (2), 235-241. doi:10.1016/j.canlet.2013.07.032

Saralamma, V. V. G., Vetrivel, P., Lee, H. J., Kim, S. M., Ha, S. E., Murugesan, R., et al. (2020). Comparative Proteomic Analysis Uncovers Potential Biomarkers Involved in the Anticancer Effect of Scutellarein in Human Gastric Cancer Cells. Oncol. Rep. 44 (3), 939-958. doi:10.3892/or.2020.7677

Schilsky, R. L., Michels, D. L., Kearbey, A. H., Yu, P. P., and Hudis, C. A. (2014). Building a Rapid Learning Health Care System for Oncology: the Regulatory Framework of CancerLinQ. J. Clin. Oncol. 32 (22), 2373-2379. doi:10.1200/ JCO.2014.56.2124

Shah, A., Stewart, A. K., Kolacevski, A., Michels, D., and Miller, R. (2016). Building a Rapid Learning Health Care System for Oncology: Why CancerLinQ Collects Identifiable Health Information to Achieve its Vision. J. Clin. Oncol. 34 (7), 756-763. doi:10.1200/JCO.2015.65.0598
Shan, S., Wu, C., Shi, J., Zhang, X., Niu, J., Li, H., et al. (2020). Inhibitory Effects of Peroxidase from Foxtail Millet Bran on Colitis-Associated Colorectal Carcinogenesis by the Blockage of Glycerophospholipid Metabolism. J. Agric. Food Chem. 68 (31), 8295-8307. doi:10.1021/acs.jafc.0c03257

Shang, H. S., Lu, H. F., Lee, C. H., Chiang, H. S., Chu, Y. L., Chen, A., et al. (2018). Quercetin Induced Cell Apoptosis and Altered Gene Expression in AGS Human Gastric Cancer Cells. Environ. Toxicol. 33 (11), 1168-1181. doi:10. 1002/tox.22623

She, T., Zhao, C., Feng, J., Wang, L., Qu, L., Fang, K., et al. (2015). Sarsaparilla (Smilax Glabra Rhizome) Extract Inhibits Migration and Invasion of Cancer Cells by Suppressing TGF-B1 Pathway. PLoS One 10 (3), e0118287. doi:10. 1371/journal.pone.0118287

Shen, K., Xi, Z., Xie, J., Wang, H., Xie, C., Lee, C. S., et al. (2016). Guttiferone K Suppresses Cell Motility and Metastasis of Hepatocellular Carcinoma by Restoring Aberrantly Reduced Profilin 1. Oncotarget 7 (35), 56650-56663. doi:10.18632/oncotarget.10992

Singh, C. K., Kaur, S., George, J., Nihal, M., Pellitteri Hahn, M. C., Scarlett, C. O., et al. (2015). Molecular Signatures of Sanguinarine in Human Pancreatic Cancer Cells: A Large Scale Label-free Comparative Proteomics Approach. Oncotarget 6 (12), 10335-10348. doi:10.18632/oncotarget.3231

Song, L., Fang, Z., Pan, C., Chen, X., Qian, X., Cai, Y., et al. (2020). BaBao Dan Suppresses Tumor Growth of Pancreatic Cancer through Modulating Transcriptional Reprogramming of Cancer-Related Genes. Front. Oncol. 10, 584330. doi: $10.3389 /$ fonc. 2020.584330

Song, M., Wu, K., Meyerhardt, J. A., Ogino, S., Wang, M., Fuchs, C. S., et al. (2018). Fiber Intake and Survival after Colorectal Cancer Diagnosis. JAMA Oncol. 4 (1), 71-79. doi:10.1001/jamaoncol.2017.3684

Sottoriva, A., Spiteri, I., Piccirillo, S. G., Touloumis, A., Collins, V. P., Marioni, J. C., et al. (2013). Intratumor Heterogeneity in Human Glioblastoma Reflects Cancer Evolutionary Dynamics. Proc. Natl. Acad. Sci. U S A. 110 (10), 4009-4014. doi:10.1073/pnas.1219747110

Spratlin, J. L., Serkova, N. J., and Eckhardt, S. G. (2009). Clinical Applications of Metabolomics in Oncology: a Review. Clin. Cancer Res. 15 (2), 431-440. doi:10. 1158/1078-0432.CCR-08-1059

Sud, A., Kinnersley, B., and Houlston, R. S. (2017). Genome-wide Association Studies of Cancer: Current Insights and Future Perspectives. Nat. Rev. Cancer 17 (11), 692-704. doi:10.1038/nrc.2017.82

Sun, R., Gu, J., Chang, X., Liu, F., Liang, Y., Yang, X., et al. (2021). Metabonomics Study on Orthotopic Transplantion Mice Model of colon Cancer Treated with Astragalus Membranaceus-Curcuma Wenyujin in Different Proportions via UPLC-Q-TOF/MS. J. Pharm. Biomed. Anal. 193, 113708. doi:10.1016/j.jpba. 2020.113708

Swaminathan, G. J., Bragin, E., Chatzimichali, E. A., Corpas, M., Bevan, A. P., Wright, C. F., et al. (2012). DECIPHER: Web-Based, Community Resource for Clinical Interpretation of Rare Variants in Developmental Disorders. Hum. Mol. Genet. 21 (R1), R37-R44. doi:10.1093/hmg/dds362

Swiatly, A., Horala, A., Matysiak, J., Hajduk, J., Nowak-Markwitz, E., and Kokot, Z. J. (2018). Understanding Ovarian Cancer: iTRAQ-Based Proteomics for Biomarker Discovery. Int. J. Mol. Sci. 19 (8). doi:10.3390/ijms19082240

Tan, Y. K., and Fielding, J. W. (2006). Early Diagnosis of Early Gastric Cancer. Eur. J. Gastroenterol. Hepatol. 18 (8), 821-829. doi:10.1097/00042737-20060800000004

Tian, Y., Xu, Q., Sun, L., Ye, Y., and Ji, G. (2018). Short-chain Fatty Acids Administration Is Protective in Colitis-Associated Colorectal Cancer Development. J. Nutr. Biochem. 57, 103-109. doi:10.1016/j.jnutbio.2018.03.007

Valdés, A., García-Cañas, V., Artemenko, K. A., Simó, C., Bergquist, J., and Cifuentes, A. (2017). Nano-liquid Chromatography-Orbitrap MS-based Quantitative Proteomics Reveals Differences between the Mechanisms of Action of Carnosic Acid and Carnosol in Colon Cancer Cells. Mol. Cell Proteomics 16 (1), 8-22. doi:10.1074/mcp.M116.061481

Wang, C. Z., Yu, C., Wen, X. D., Chen, L., Zhang, C. F., Calway, T., et al. (2016). American Ginseng Attenuates Colitis-Associated Colon Carcinogenesis in Mice: Impact on Gut Microbiota and Metabolomics. Cancer Prev. Res. (Phila) 9 (10), 803-811. doi:10.1158/1940-6207.CAPR-15-0372

Wang, S. M., Yang, P. W., Feng, X. J., Zhu, Y. W., Qiu, F. J., Hu, X. D., et al. (2021). Apigenin Inhibits the Growth of Hepatocellular Carcinoma Cells by Affecting the Expression of microRNA Transcriptome. Front. Oncol. 11, 657665. doi:10. 3389/fonc.2021.657665 
Wang, X., Chen, Y., Han, Q. B., Chan, C. Y., Wang, H., Liu, Z., et al. (2009). Proteomic Identification of Molecular Targets of Gambogic Acid: Role of Stathmin in Hepatocellular Carcinoma. Proteomics 9 (2), 242-253. doi:10. 1002/pmic.200800155

Wani, N. A., Zhang, B., Teng, K. Y., Barajas, J. M., Motiwala, T., Hu, P., et al. (2018). Reprograming of Glucose Metabolism by Zerumbone Suppresses Hepatocarcinogenesis. Mol. Cancer Res. 16 (2), 256-268. doi:10.1158/15417786.MCR-17-0304

Wong, S. H., Zhao, L., Zhang, X., Nakatsu, G., Han, J., Xu, W., et al. (2017). Gavage of Fecal Samples from Patients with Colorectal Cancer Promotes Intestinal Carcinogenesis in Germ-free and Conventional Mice. Gastroenterology 153 (6), 1621-e6. e6. doi:10.1053/j.gastro.2017.08.022

Xi, Z., Yao, M., Li, Y., Xie, C., Holst, J., Liu, T., et al. (2016). Guttiferone K Impedes Cell Cycle Re-entry of Quiescent Prostate Cancer Cells via Stabilization of FBXW7 and Subsequent C-MYC Degradation. Cell Death Dis 7 (6), e2252. doi:10.1038/cddis.2016.123

Xie, G., Wang, C. Z., Yu, C., Qiu, Y., Wen, X. D., Zhang, C. F., et al. (2015). Metabonomic Profiling Reveals Cancer Chemopreventive Effects of American Ginseng on Colon Carcinogenesis in Apc(Min/+) Mice. J. Proteome Res. 14 (8), 3336-3347. doi:10.1021/acs.jproteome.5b00388

Xu, W. W., Zheng, C. C., Huang, Y. N., Chen, W. Y., Yang, Q. S., Ren, J. Y., et al. (2018). Synephrine Hydrochloride Suppresses Esophageal Cancer Tumor Growth and Metastatic Potential through Inhibition of Galectin-3-AKT/ ERK Signaling. J. Agric. Food Chem. 66 (35), 9248-9258. doi:10.1021/acs. jafc. 8 b0 4020

Yanovich, G., Agmon, H., Harel, M., Sonnenblick, A., Peretz, T., and Geiger, T. (2018). Clinical Proteomics of Breast Cancer Reveals a Novel Layer of Breast Cancer Classification. Cancer Res. 78 (20), 6001-6010. doi:10.1158/0008-5472. CAN-18-1079

Zamanian-Azodi, M., Rezaie-Tavirani, M., Heydari-Kashal, S., Kalantari, S., Dailian, S., and Zali, H. (2012). Proteomics Analysis of MKN45 Cell Line before and after Treatment with Lavender Aqueous Extract. Gastroenterol. Hepatol. Bed Bench 5 (1), 35-42.

Zhang, H., Chen, L., Bu, H. Q., Yu, Q. J., Jiang, D. D., Pan, F. P., et al. (2015). Effects of Emodin on the Demethylation of Tumor-Suppressor Genes in Pancreatic Cancer PANC-1 Cells. Oncol. Rep. 33 (6), 3015-3023. doi:10.3892/or.2015.3914 Zhang, Y., He, C., Qiu, L., Wang, Y., Qin, X., Liu, Y., et al. (2016). Serum Unsaturated Free Fatty Acids: A Potential Biomarker Panel for Early-Stage Detection of Colorectal Cancer. J. Cancer 7 (4), 477-483. doi:10.7150/jca.13870

Zhu, Y., Liu, Y., Qian, Y., Dai, X., Yang, L., Chen, J., et al. (2014). Research on the Efficacy of Celastrus Orbiculatus in Suppressing TGF-B1-Induced EpithelialMesenchymal Transition by Inhibiting HSP27 and TNF- $\alpha$-Induced NF- $\kappa B$ / Snail Signaling Pathway in Human Gastric Adenocarcinoma. BMC Complement. Altern. Med. 14, 433. doi:10.1186/1472-6882-14-433

Conflict of Interest: The authors declare that the research was conducted in the absence of any commercial or financial relationships that could be construed as a potential conflict of interest.

Publisher's Note: All claims expressed in this article are solely those of the authors and do not necessarily represent those of their affiliated organizations, or those of the publisher, the editors and the reviewers. Any product that may be evaluated in this article, or claim that may be made by its manufacturer, is not guaranteed or endorsed by the publisher.

Copyright (c) 2022 Dai, Liu, Xiang, Li, Xi and Xu. This is an open-access article distributed under the terms of the Creative Commons Attribution License (CC BY). The use, distribution or reproduction in other forums is permitted, provided the original author(s) and the copyright owner(s) are credited and that the original publication in this journal is cited, in accordance with accepted academic practice. No use, distribution or reproduction is permitted which does not comply with these terms. 